FEDERAL RESERVE BANK OF SAN FRANCISCO

WORKING PAPER SERIES

\title{
Testing the Strong-Form of Market Discipline: The Effects of Public Market Signals on Bank Risk
}

\author{
Simon Kwan \\ Federal Reserve Bank of San Francisco
}

Working Paper 2004-19

http://www.frbsf.org/publications/economics/papers/2004/wp04-19bk.pdf

The views in this paper are solely the responsibility of the authors and should not be interpreted as reflecting the views of the Federal Reserve Bank of San Francisco or the Board of Governors of the Federal Reserve System. 
Preliminary Draft

Please Do Not Quote without Permission

\title{
Testing the Strong-Form of Market Discipline: The Effects of Public Market Signals on Bank Risk
}

\author{
Simon Kwan \\ Federal Reserve Bank of San Francisco
}

May 2004

\begin{abstract}
Under the strong-form of market discipline, publicly traded banks that have constantly available public market signals from their stock (and bond) prices would take less risk than non-publicly traded banks because counterparties, borrowers, and regulators could react to adverse public market signals against publicly traded banks. In comparing the credit risk, earnings risk, capitalization, and failure risk between publicly traded and non-publicly traded banks, the evidence in this paper rejects the strong-form of market discipline. In fact, the findings indicate that banking organizations tend to take more risk when they were publicly traded than when they were privately owned.
\end{abstract}

Key words: market discipline, bank risk-taking

JEL classification: G21, G32, G34

Please send correspondence to: Simon Kwan, Research Advisor, Federal Reserve Bank of San Francisco, 101 Market Street, San Francisco, CA 94105, U.S.A.

Telephone: 415-974-3485; Fax: 415-974-2168; E-mail: simon.kwan@sf.frb.org

Helpful comments from Mark Flannery, Fred Furlong, John Krainer, Jose Lopez, Marc Saidenberg, Philip Strahan, and seminar participants at the Australian Prudential Regulatory Authority and the Hong Kong Monetary Authority are gratefully acknowledged. An earlier version of this paper was presented at the Federal Reserve System Conference on Financial Structure and Regulation, and the Columbia/New York Fed Conference on Disclosure and Market Discipline of Financial Firms. Thanks are also due to Irene Wang for excellent research assistance. The views expressed in this paper are those of the author's and do not necessarily represent the views of the Federal Reserve Bank of San Francisco or the Federal Reserve System. 


\section{Testing the Strong-Form of Market Discipline: The Effects of Public Market Signals on Bank Risk}

\section{Introduction}

In recent years, policy makers and bank regulators have been warming up to the idea of leveraging market forces to supplement banking supervision, in order to enhance the safety and soundness of the banking system. The motivations for promoting market discipline in banking are three folds. First, with the growing complexity of banking organizations, banking supervision becomes increasingly demanding in terms of both scope and depth. To partially offset this development, it is argued that regulators ought to enlist the market on their side to help safeguard the increasingly complex banking industry. This may include relying more on monitoring by market participants such as stockholders, bondholders, and banks' counterparties, as well as mandating banking firms to issue publicly traded securities on a regular basis to subject them to ongoing market issuance tests. ${ }^{1}$ Second, to the extent that market signals are freely available at a relatively high frequency, as compared to the bank examination process which is both costly and sparse, the timely information embedded in bank security prices should be valuable to supervisors, alerting them to potential problems early and assisting them in allocating scarce supervisory resources. Third, one of the prerequisites for market discipline is that uninsured bank debt holders and equity holders must have incentives to monitor bank risks. Thus, promoting market discipline also means avoiding the unduly extension of the bank safety net, reining in both regulatory forbearance and the invoking of "too-big-to-fail."

Both the Federal Reserve and the Basel Committee on Banking Supervision are actively

${ }^{1}$ See, for example, the Federal Reserve Staff Study (1999). 
promoting the concept of market discipline in banking. In the New Basel Capital Accord to be implemented by 2006, market discipline is prominently placed as one of the three pillars, along with capital regulation (Pillar One) and banking supervision (Pillar Two), in safeguarding the banking system. In the U.S., the Chairman of the Federal Reserve System, Alan Greenspan, has remarked that "the real pre-safety-net discipline was from the market, and we need to adopt policies that promote private counterparty supervision as the first line of defense for a safe and sound banking system. Uninsured counterparties must price higher or simply not deal with banking organizations that take on excessive risk."

While the concept of market discipline is intuitively appealing, there has been very little research on whether the availability of market information has any effects on bank risk-taking. In this paper, I compare bank risk-taking between two classes of banking firms: publicly traded banking organizations with constant market signals from their stock (and bond) prices versus privately owned banking companies that do not send out such market signals. To isolate the effects of market signals on bank risk-taking, I control for firm size, portfolio characteristics, time effects, and geographic effects across the two classes of firms in conducting the comparisons. Studying the effects of the availability of market signals on bank risk-taking directly tests a specific channel of market discipline in banking.

This specific channel of market discipline, thereafter referred to as the "strong-form of market discipline," is most closely related to Greenspan (2001). The way this channel of market discipline works is the following. The market prices of publicly traded securities issued by the bank reflects the latest market assessment of the bank's financial condition. In observing these

\footnotetext{
${ }^{2}$ Please see Greenspan (2001).
} 
market signals, market participants who engage in financial transactions with the bank, and regulators who conduct prudential supervision, could take certain actions to influence or force the bank to change its risk profile. For example, a bank's counterparties may limit or withdraw their trading with the bank if the counterparty risk is deemed to be unacceptable by market participants. In addition, researchers have shown that relationship banking is valuable to both banks and their client firms [see for example, Ramakrishnan and Thakor (1984), Sharpe (1990), and Diamond (1991)], and deterioration in bank durability imposes costs to borrowing firms [see for example, Slovin, Sushka, and Polonchek (1993), Gibson (1995), Kang and Stulz (2000), and Bae, Kang, and Lim (2002)]. Thus, upon observing negative market signals from its bank, a borrower may lessen its reliance on this bank to protect itself from downside risk. Finally, armed with up-to-date market information, banking regulators could use their supervisory power to force bank management to lessen its risk-taking. Just the mere threats of regulatory, borrower, and counterparty responses to unfavorable market signals by themselves have the potential to constrain bank risk-taking.

The reason I refer to this particular channel of market discipline as the strong-form of market discipline is because the disciplinary force is actually not exerted by bank stockholders nor bondholders, but by the bank's counterparties, borrowers, and regulators. This is to be distinguished from stockholders' and bondholders' discipline. It is an important distinction because stockholders' and bondholders' discipline works on improving the information efficiency of bank security prices in reflecting bank risk-taking. In pricing bank risk-taking properly, stockholders and bondholders try to force banks to maximize shareholders' and bondholders' wealth, respectively, but that does not necessarily mean limiting bank risk-taking 
pe se. For example, Merton (1974) studied equity claims in the option pricing framework and showed that the value of stockholders' claims could increase with the underlying asset volatility, resulting in incentive conflicts between stockholders and bondholders. ${ }^{3}$ And while a bank's existing bondholders generally do not like to see any increases in bank risk, a risky bank can still issue high-yield debts to marginal bondholders, so long as those risks are properly priced. Hence, under certain conditions, stockholders may actually like bank risk-taking, and marginal bondholders may not care about the level of bank risk as long as they are properly compensated for bearing such risks. Only the discipline from counterparties, borrowers, and regulators has the unambiguous constraining effect on bank risk-taking. ${ }^{4}$ Because this particular channel of discipline relies on observing information efficient bank security prices by market participants and regulators, stockholders and bondholders discipline is a necessary condition for the strongform of market discipline to work.

Thus, in this paper, I define the strong-form of market discipline to be the effects of publicly available market signals from bank-issued securities that lead to less risk-taking by the issuing bank, relative to otherwise similar banks that do not issue publicly traded securities. Therefore, my criteria for the strong-form of market discipline to work is that not only does it force a publicly traded bank to make the appropriate trade-off between risk and return, it must be able to reduce the bank's overall risk relative to non-publicly traded banks that are not subject to

3 This stockholder-bondholder conflict is well known in the corporate finance literature. For example, see Smith and Warner (1979).

4 This is true in spite of the fact that stockholders and bondholders may have different incentives for bank risk-taking, so long as market participants and regulators understand their differences in incentives and react to changes in stock and bond prices accordingly. 
the strong-form of market discipline. Also note that it is the net difference in risk-taking between a privately held and a publicly traded bank that counts, not just the marginal change in risk-taking by a publicly traded banking organization because of its market signal..$^{5}$

Previous research on market discipline in banking focuses narrowly on the information efficiency of bank security prices. They generally ask the question: do bank-issued securities, including bank stocks and subordinated debts, accurately reflect bank risk-taking? While the answer seems to be yes, ${ }^{6}$ it only means that the market is able to price risk correctly, thus forcing banks to make the appropriate trade-off between risk and return. As I argued earlier, this kind of market discipline may not have any effects on bank risk-taking. Here, condition on the information efficiency of bank security prices, the strong-form of market discipline takes the concept of market discipline to a higher level. It raises the hurdle for the role of market forces to safeguard the banking system by asking the following question: does the presence of readily available bank security prices result in lower bank risk-taking, on net, by publicly traded banking organizations?

There has been very little research into whether market forces are capable of influencing banking firms' behavior. Bliss and Flannery (2002) is the only paper to my knowledge that looked into this question. Using a sample of publicly traded banking companies, they found little evidence that stock or bond investors influence managerial actions, casting doubts on the

5 The presence of public market signal may lead a publicly traded bank to take less risk at the margin. However, in order for the strong-form of market discipline to be considered successful in reducing bank risk-taking, the overall risk of a publicly traded bank must be less than the overall risk of an otherwise similar privately held bank.

${ }^{6}$ For details, see the survey paper by Flannery (1998). 
effectiveness of the market in shaping management behavior. In this paper, rather than looking at managerial actions, I focus on the end results by comparing the risk-taking of publicly traded banking firms versus their privately held counterparts, and the forces of market discipline come from counterparties, borrowers, and regulators, instead of stock and bond holders. Although my criteria for the operation of the strong-form of market discipline is whether a banking organization issues stocks that are publicly traded, the analysis subsumes any signaling effects from the bond market, since all banks that issue bonds publicly have publicly traded stocks.

While my regression analysis does not find significant difference in asset risk, earnings volatility, and capital between public and private banking companies, I do find that publicly traded banking firms tend to receive a significantly worse supervisory rating than otherwise similar privately owned companies. Upon following a subset of banking companies that went public (or private) during the study period, I find that the same banking organizations tend to have more asset risk and hold less capital when they were public traded than when they were privately owned. Overall, the results reject the strong-form of market discipline in banking.

The rest of the paper is organized as follows. Section II describes the data and provides summary statistics for the sample banking organizations. Section III discusses the seven bank risk measures to be used in this study, and the two different methodologies in testing the strongform of market discipline. Empirical findings are presented in Section IV. Section V summarizes and concludes this study.

\section{Data}

To construct a sample of publicly traded and privately held banking firms, I begin with all 
bank holding companies (BHCs) that file the Consolidated Financial Statements for Bank Holding Companies (FR Y-9C) with the Federal Reserve from 1986 to 2001.7 Federal regulation requires all BHCs with total consolidated assets of $\$ 150$ million or more to file this report quarterly. To avoid double counting of multi-tiered BHCs, only the top tier BHCs are retained for analysis. I then match these BHCs to their commercial bank subsidiaries who file the Report of Condition and Income (Call Report) to find out the total banking assets controlled by each BHC. To ensure that my sample includes only BHCs that engage mainly in banking activities, BHCs that have more than 10 percent of assets in non-banking subsidiaries are excluded from the analysis. To control for the geographic location of the BHC, I use the Federal Reserve District in which the BHC is located and exclude all off-shore BHCs. To control for the possibility of unusual performance due to de novo banking, bank failure, IPO, and takeover, the first year and the last year of observations for each BHC that does not have a complete time-series of data in either the public or the private sample are dropped from the analysis. ${ }^{8}$ The above criteria yields a preliminary sample of 12,518 firm-years.

To determine whether a $\mathrm{BHC}$ is publicly traded in a certain year, I match the BHC data with the common stock data from the Center for Rearch in Security Price (CRSP) by the name of the banking company. To confirm that a BHC's stock is the one identified in the CRSP data, I use the CUSIP number from CRSP to look up the total assets with the same CUSIP in Compustat and compare it to the reported total assets in the Y-9C. This classification method assigns 3,313

7 Thereafter, the term bank refers to bank holding company.

8 Admittedly, this procedure eliminates only the short-term abnormalies in firm performance. 
observations to the public sample and 9,205 observations to the private sample.

To compare the risk-taking between publicly traded and non-publicly traded BHCs, an important dimension to control for is the scale effect, since publicly traded banks tend to be larger than those that are privately held. Another reason for controlling the size effect is that large money center or regional banks often have a different emphasis on their product and funding mix than smaller community banks. Hence, in comparing between the two types of banking firms, the two samples of publicly traded and privately held BHCs should be as homogenous as possible.

To control for firm size, I assign each sample observation into size quartile. Since public firms tend to be larger than private firms, firm size from the private sample is used to determine the cutoffs for each size class to ensure that for each size class, public and private firms are comparable in size. Specifically, for each sample year, I first sort the total assets of all private BHCs. Firms with total assets at or above the $90^{\text {th }}$ percentile are assigned to Size 1; firms with total assets at or above the $75^{\text {th }}$ percentile but less than the $90^{\text {th }}$ percentile are assigned to Size 2 ; firms with total assets at or above the $50^{\text {th }}$ percentile but less than the $75^{\text {th }}$ percentile are assigned to Size 3; and firms with total assets less than the $50^{\text {th }}$ percentile are assigned to Size 4 . Based on the minimum and the maximum total assets of private BHCs in each size class at each year, I compare the total assets of each public BHC at each year to those size class cutoffs and assign public BHCs to size class accordingly. For the public BHCs whose total assets exceed the maximum total assets of private BHCs in Size 1, these very large public BHCs are eliminated from the sample. Hence, for each size class at each year, the largest BHC will always be a private company. This is to ensure that my results are not driven by the very large, publicly 
traded BHCs that are not directly comparable to those that are privately held. ${ }^{9}$ In addition, after all remaining public BHCs are assigned to each of the four size classes, I find out the smallest public BHC in Size 4 at each year. All private BHCs whose total assets are smaller than the smallest public BHC at each year are also eliminated from the sample. Again, this is to ensure that the results are not driven by the very small privately held BHCs that do not have directly comparable public counterparts. Dropping the very large public BHCs and the very small private BHCs from the sample reduces the sample size to 10,821 firm-years.

Table 1 provides descriptive statistics for the final sample covering the entire period from 1986 to 2001 . As expected, the number of observations for the public sample is skewed towards the larger size quartile, with 1,812 observations in the Size 1 public sample but only 986 in the private sample for that size class. The private sample has the exactly opposite skew, with 3,091 observations in the private sample for Size 4 firms but only 149 observations in the public sample. Except for the largest size class, the mean and median total assets of the sample public and private firms are very similar, suggesting that these firms with different ownership structures are indeed comparable in size. In the largest size class, despite my effort to control for size differences, the mean and the median public firms are almost twice as large as the average private firm. Nevertheless, we know for sure that the largest firm in that size class is always a private firm in each of the sampling year. For robustness, the analysis is done separately for each size class, and I further control for the within size class scale effect by using the log of total

${ }^{9}$ While excluding the very large publicly traded BHCs from the sample is an empirical necessity, it limits the analysis of very large banking firms. Market discipline of very large banking firms may be of particular interest due to the potential systemic implications of large bank failures. 
assets as a control variable in the multi-variate analysis.

Table 1 also shows certain firm characteristics for the public and private samples. Regarding portfolio composition, both the loan-to-asset ratio and the C\&I loan ratio (defined as the ratio of commercial and industrial loans to total loans) are quite similar between the public and private $\mathrm{BHCs}$ in each size class, and both ratios do not seem to vary much across size classes. For the consumer loan ratio (defined as the ratio of consumer loans to total loans), both the mean and the median are fairly stable across the four size classes in the private sample, but are declining from Size 1 to Size 4 in the public sample. For the fee ratio (defined as the ratio of total noninterest income to the sum of interest and noninterest income), while larger BHCs tend to derive a larger share of their income from fee-based activities than smaller BHCs, the fee ratio is quite similar between the private and public BHCs within each size class. Turning to the funding mix, both the core deposit ratio (defined as the ratio of demand and savings deposits to total assets) and the large $\mathrm{CD}$ ratio (defined as the ratio of large CDs to total assets) are remarkably similar between public and private BHCs within each size class. Overall, there does not seem to be notable differences in average portfolio composition and funding mix between publicly traded and privately held BHCs, especially after grouping firms into size classes.

\section{Methodology}

Two sets of empirical analysis are conducted to test the strong-form of market discipline. In the first method, I use regression analysis to compare the risk-taking between publicly traded BHCs that are subject to the strong-form of market discipline versus privately owned BHCs that are not, controlling for certain firm characteristics. In the second method, a set of BHCs that 
went public (or private) during the period 1986 to 2001 are identified. The changes in risk-taking of these BHCs three years before and three years after they went public (or private) are then compared to a control group of BHCs in the same size class that were always public or always private over the same seven years period. In both methods, multiple measures of bank risktaking are analyzed. These measures are designed to capture the BHCs' credit risk, earnings volatility, capitalization, and failure risk.

In general, credit risk represents the major source of risk exposures in banking firms. It is measured by: (i) BADLOAN, defined as the ratio of the sum of past due and nonaccural loans to total loans; and (ii) CHARGEOFF, defined as the ratio of net charge-offs to total loans. Both BADLOAN and CHARGEOFF should reflect the quality of the banking firm's loan portfolio. Earnings volatility is measured by SDROA and SDROE, the standard deviations of quarterly return on assets and return on equity, respectively. They should reflect the earnings risk of the banking company, encompassing not only credit risk but also other sources of bank risks. Given a bank's risk exposure, capitalization measures the bank's ability to withstand unexpected losses. It is measured by CAPITAL, defined as the ratio of equity capital, including preferred stocks, common stocks, and retained earnings, to total assets. Since a key role of bank capital is to support bank risk-taking, a bank's capitalization should be taken into consideration in evaluating bank risks. BADLOAN, CHARGEOFF, SDROA, SDROE and CAPITAL are all expressed in percent.

While each of the above variables represents different ways to measure bank risk, it would be useful to synthesize these different risk measures into risk scores that summarize a banking firm's risk-taking. I use two risk scores in this paper. One is the Z-score derived by 
Boyd and Graham (1988) that measures a banking firm's failure risk or the probability of bankruptcy. Another one is the BOPEC rating assigned by bank examiners in their course of prudential supervision. In testing the strong-form of market discipline, both the Z-score and the BOPEC rating are of particular interest because they directly address the issue of bank safety and soundness.

To measure the failure risk, bankruptcy is defined as the situation where losses exceed a banking firm's capital. Denote the return on assets as $\mathrm{r}$, and the capital to asset ratio as $\mathrm{k}$, then the probability of bankruptcy can be written as:

$$
\mathrm{p}(\mathrm{r}<-\mathrm{k})=\int_{-\infty}^{-\mathrm{k}} \phi(\mathrm{r}) \mathrm{dr}
$$

where $\mathrm{p}(\bullet)$ is a probability and $\phi(\mathrm{r})$ is the probability density function of the random variable $\mathrm{r}$. Assuming $\mathrm{r}$ is normally distributed, then equation (1) may be rewritten as:

$$
\mathrm{p}(\mathrm{r}<-\mathrm{k})=\int_{-\infty}^{z} N(0,1) \mathrm{dz}
$$

and

$$
\mathrm{z}=(-\mathrm{k}-\mu) / \sigma
$$

where $\mu$ is the mean of the $r$ distribution, $\sigma$ is the standard deviation of $r$, and $z$ is the number of standard deviations below the mean by which profits would have to fall to wipe out the firm's capital. Thus, the value of $\mathrm{z}$ is a useful indicator of the probability of bankruptcy. ${ }^{10}$ To

${ }^{10}$ Note that even if $\mathrm{r}$ is not normally distributed, $\mathrm{z}$ is still a useful failure risk measure so long as $\mu$ and $\sigma$ exist. Invoking the Bienayme-Tchebycheff inequity and $\mathrm{p}(\mathrm{r} \leq-\mathrm{k}) \leq[\sigma /(\mu+\mathrm{k})]^{2}$. 
implement equation (3), I use the sample estimates of $\mu$ and $\sigma$ and rewrite the estimated value of $-\mathrm{z}$ (since $\mathrm{z}$ is a negative number) as the $\mathrm{Z}$-score. Note that a higher value of $\mathrm{Z}$-score is associated with a lower probability of failure.

Whereas the Z-score measures bank failure risk using publicly observable financial data, the BOPEC rating measures BHCs' safety and soundness based on private information obtained from bank examiners' on-site inspections. As the supervisor of bank holding companies, the Federal Reserve conducts full-scope, on-site inspections of BHCs on a regular basis, usually once a year. During the on-site inspection, the Federal Reserve examiners have access to detailed loan-by-loan information and internal documents that are tightly guarded by bank management and not available to the public. At the conclusion of an inspection, the supervisory team assigns the BHC a numerical rating, called a composite BOPEC rating, that summarizes in the opinion of the examiners the overall health and financial condition of the BHC. More specifically, the five areas of supervisory concerns underlying the BOPEC rating include the BHC's bank subsidiary (the $\mathrm{B}$ in the BOPEC), other nonbank subsidiaries $(\mathrm{O})$, parent company $(\mathrm{P})$, earnings $(\mathrm{E})$, and capital adequacy (C). BOPEC ratings are assigned according to an absolute scale ranging from 1 , which is the best rating, to 5 , which is the worst rating. BOPEC ratings are confidential and are not made available to the public.

Table 2 presents descriptive statistics of the seven measures of bank risk. In this Table, I also compare the distributions of each risk measure between publicly traded and privately held BHCs using the non-parametric Wilcoxon Rank Sum test separately for each size class. The

Then $\mathrm{z}$ represents the upper-bound or worst case probability of bankruptcy. See Boyd and Graham (1988) and Roy (1952). 
Wilcoxon Z-statistic is approximately normally distributed under the null hypothesis that the private sample and the public sample have the same distribution. This test statistic is calculated for the smaller sample of the two samples being compared, i.e., the private sample for Size 1 firms and the public sample for the other three size quartiles.

\section{A. Regression Analysis}

In the regression analysis, to formally test whether public ownership has any effect on bank risk-taking, two versions of the following regression model are estimated:

$$
\mathrm{Y}_{\mathrm{i}, \mathrm{t}}=\alpha+\beta \mathrm{X}_{\mathrm{i}, \mathrm{t}}+\gamma \mathrm{T}_{\mathrm{t}}+\delta \mathrm{D}_{\mathrm{i}}+\lambda \text { PUBLIC }_{\mathrm{i}}+\epsilon_{\mathrm{i}, \mathrm{t}}
$$

where

$\mathrm{Y}_{\mathrm{i}, \mathrm{t}}$ is one of the seven measures of bank risk;

$\mathrm{X}_{\mathrm{i}, \mathrm{t}}$ is a vector of firm characteristic variables;

$\mathrm{T}_{\mathrm{t}}$ is a vector of time-effect dummy variables;

$D_{i}$ is a vector of dummy variables for the Federal Reserve District where the BHC is located; PUBLIC is a dummy variable that equals one for publicly traded BHCs, zero otherwise;

$\alpha, \beta, \gamma, \delta$, and $\lambda$ are regression coefficients; and $\epsilon_{\mathrm{i}, \mathrm{t}}$ is the disturbance term.

In the first version of the model, the vector $\mathrm{X}_{\mathrm{i}, \mathrm{t}}$ of firm characteristics, except for firm size, is omitted from equation (4). The time-effect dummies control for macroeconomic effects, and the District dummies control for location effects. Firm size, measured by the log of total assets, controls for any residual scale effects after grouping the sample banks into size classes. To the extent that firm characteristics, such as portfolio composition, partially determine bank risk-taking, omitting them from the model tests the effects of public ownership on overall bank 
risk-taking. That is, in this version of the model, I only control for the pure exogenous factors including the macroeconomic effects and the location effects.

One may argue that different banks may have different business strategies, including loan portfolio concentration and funding mix, so that no two banks are alike. Thus, in comparing bank risk-taking between two classes of banks, it may be preferable to control for their different individual characteristics. ${ }^{11}$ In the second version of the model, firm characteristics are included as additional control variables. The vector of firm characteristic variables falls into two categories: portfolio composition and funding mix. To control for portfolio composition, the loan-to-asset ratio, the C\&I loans to total loans ratio, and the consumer loans to total loans ratio, are included as explanatory variables. Since bank risk-taking is partially determined by loan portfolio composition, controlling for portfolio mix tests whether publicly traded banks take more or less risk within the same loan categories as privately held banks. To control for funding mix, I include the core deposits to total assets ratio, and the large CDs to total assets ratio in the model. These two variables control for the effects of different funding strategies on bank risktaking.

The coefficient of PUBLIC, $\lambda$, tests the effects of having public market signals on bank risk-taking. If the presence of publicly available market signals has no net effect on bank risktaking, $\lambda$ should be indistinguishable from zero. Finding significant $\lambda$ coefficients provides evidence for the strong-form of market discipline in banking. Specifically, the strong-form of market discipline predicts a negative $\lambda$ for the BADLOAN, CHARGEOFF, SDROA, SDROE, do not.

11 This begs the question of why some banks choose a riskier strategy while other banks 
and BOPEC regressions, and a positive $\lambda$ for the CAPITAL and Z-SCORE regressions.

Pooled time-series cross-section observations are used to fit the regression models, using the full sample as well as the sub-samples from each of the four size classes. In the panel regressions where the observations per each cross sectional unit may not be independent, I use the robust standard error that only assumes independence across banks but not within banks to draw inferences.

In the BADLOAN, CHARGEOFF, CAPITAL, and BOPEC regressions, the data consist of annual observations and the time-effect dummies are year dummies. In the SDROA, SDROE, and Z-SCORE regressions, the dependent variables are computed (estimated) using quarterly observations over three non-overlapping time periods: 1986-1990, 1991-1995, and 1996-2001. ${ }^{12}$ Because in these regressions, each bank has at most three time-series observations (rather than 16 annual observations), the total number of observations used to fit the models is much smaller. Also, in order for the dependent variables to be meaningful, firms with less than eight quarters of non-missing observations in each sub-period are excluded, which also contributes to the reduction in the total number of observations. In these regressions, the firm characteristic variables are averages over each sub-period, and the time-effect dummies are sub-period

12 The first sub-period was characterized by tremendous difficulties in the banking industry. The banking sector was suffering from the worst crisis since the Great Depression. The total number of bank failures peaked at 279 in 1988 while exceeding 200 in both 1987 and 1989. During the second sub-period, the banking industry was gradually coming out of the crisis while the economy was recovering from the recession after the first Gulf War. The banking sector was stabilizing and returning to profitability. The last sub-period was marked by a fast growing economy and financial market booms. Profitability of banking firms soared to record level while asset quality improved markedly. Those were the banner years of the banking industry. 
dummies.

One potential econometric issue of using equation (4) to test the strong form of market discipline is the issue of selectivity bias. When publicly traded BHCs are systematically different from privately held $\mathrm{BHCs}$ due to some unobservable characteristics and these unobservable characteristics are related to bank risk-taking, the coefficient of PUBLIC in equation (4) could be a biased estimate of the marginal effect of having public market signal on bank risk, similar to the omitted variable problem. However, in testing the strong form of market discipline, I am not interested in just the marginal effect of PUBLIC (see footnote 5), but the net observable differences in bank risk between the two classes of firms. Thus, for the purpose of measuring the net differences in risk exhibited by BHCs with and without public market signals, the coefficient of PUBLIC in (4) will measure precisely that.

\section{B. Same Firm Comparison}

In the same-firm-comparison, I identify a subset of BHCs in my sample that changed from private to public status, or vice versa during the study period. The risk of a BHC when it was publicly traded relative to its control group of similar sized banks that did not change status is then compared to the risk of the same $\mathrm{BHC}$ when it was privately owned relative to its peer group. Thus, I define the Change in Relative Risk (CRR) for the ith BHC that went public (private) as:

$$
\mathrm{CRR}_{\mathrm{i}}=\left[\overline{\mathrm{Y}}_{\text {Public, } \mathrm{i}}-\overline{\mathrm{Y}}_{\text {Public }}^{\mathrm{PEER}}\right]-\left[\overline{\mathrm{Y}}_{\text {Private, } \mathrm{i}}-\overline{\mathrm{Y}}_{\text {Private }}^{\text {PEER }}\right]
$$

When $\mathrm{Y}$ is equal to BADLOAN, CHARGEOFF, SDROA, SDROE, and BOPEC, the first term in equation (5) is either the mean or the median difference in risk between the ith BHC and 
its peer group of similar size BHCs over the period after (before) the ith BHC went public (private). This is then compared to the second term, which is the mean or the median difference in risk over the period before (after) the ith $\mathrm{BHC}$ went public (private). When $\mathrm{Y}$ is equal to SDROA, SDROE, or Z-SCORE, the CRR is computed using the time series of quarterly data before and after the ith $\mathrm{BHC}$ went public (private). The peer group includes only BHCs that were always public or always private over the sampling period. In order for the $\mathrm{CRR}_{\mathrm{i}}$ to be meaningful, I require the ith $\mathrm{BHC}$ to have at least three years of data before, and three years of data after it went public (private), and I do not use the data from the year the BHC went public (private).

A negative (positive) CRR for BADLOAN, CHARGEOFF, SDROA, SDROE, and BOPEC, and a positive (negative) CRR for CAPITAL and Z-SCORE imply that the risk of the ith BHC was lower (higher) when it was publicly traded than when it was privately owned. I use both the t-test and the non-parametric signed rank test to draw inferences about the distributions of the CRRs to test the strong-form of market discipline.

\section{Empirical Findings}

\section{A. Regression Analysis}

The discussion of the regression results is organized into four sub-sections: credit risk, earnings volatility, capitalization, and failure risk. In each of the regression tables, the left hand panel contains the results of estimating the model without controlling for firm characteristics, and the right hand panel contains the results of estimating the full model. In both cases, estimates of the time effect dummies and the District dummies are not reported but are available upon 
request.

\section{Credit Risk}

Table 3 reports the results of the BADLOAN regression. In the left hand panel, the coefficient of PUBLIC is indistinguishable from zero for both the full sample and for each of the four size classes, so is the coefficient for firm size. In the right hand panel where firm characteristics are included as control variables, firm size has a significantly negative effect on BADLOAN for the full sample, possibly due to better diversification opportunities among larger firms. The size effect disappears in the size based regressions. Regarding the other control variables, the coefficient of the loan-to-asset ratio is positive and marginally significant for the Size 1 regression, indicating that the amount of nonperforming loans is directly related to loan quantity. Within the loan portfolio, it is quite clear that the proportion of consumer loans has a significantly negative effect on BADLOAN; the coefficient of the consumer loan ratio is significantly negative and is robust across the four size classes. This suggests that concentrating in consumer lending can reduce credit risk, possibly due to the diversification benefit of lending to a large pool of individual borrowers. In contrast, the coefficient of the C\&I loan ratio is positive and marginally significant for the full sample and BHCs in Size 4, indicating that concentrating in C\&I lending raises the nonperforming loan ratio. The fee ratio is found to have a significantly positive effect on BADLOAN for the full sample and three of the four size classes. One interpretation is that in making loans to risky borrowers, banks charge high risk borrowers higher fees. The higher fees may be part of the loan pricing, either to supplement the loan rate where usury ceiling is binding or simply because of the lack of bargaining power by high risk borrowers. High risk borrowers also may be more likely to purchase credit enhancements from 
their banks, such as standby letters of credit. Regarding the funding mix, the coefficient of the large $\mathrm{CD}$ ratio has a significantly positive effect on BADLOAN, suggesting that banks may be more willing to use relatively costly CDs to fund their high yield loans. Turning to the test variable, the coefficient of PUBLIC is again insignificantly different from zero, indicating that public ownership has no effect on the amount of nonperforming loans, even after controlling for asset composition and funding mix.

Results of the CHARGEOFF regressions are presented in Table 4. In the left hand panel, the coefficient of PUBLIC in general is insignificantly different from zero, but is significantly positive for BHCs in Size 3. In the right hand panel, estimates of the control variables for firm characteristics are broadly consistent with those in the BADLOAN regressions. Some evidence of firm size having a negative effect on loan charge-offs is detected. While the C\&I loan ratio is found to have a stronger effect on charge-offs (than bad loans), the consumer loan ratio is actually found to have a positive effect on charge-offs, albeit only for the full sample and BHCs in Size 1. Both the fee ratio and the large CD ratio are found to have a positive effect on chargeoffs. Similar to the left hand panel, the coefficient of PUBLIC is insignificant except for the Size 3 regression.

In summary, the credit risk between publicly traded BHCs and non-publicly traded BHCs is statistically indistinguishable. There is some evidence that publicly traded BHCs in Size 3 tend to have more loan charge-offs than non-publicly traded BHCs, which is in contradiction to the strong-form of market discipline.

\section{Earnings Volatility}

Table 5 reports the estimates of the SDROA regressions. The results have some striking 
similarities to those of the BADLOAN and CHARGEOFF regressions. In the left hand panel, publicly traded BHCs in general exhibit similar ROA volatility as non-publicly traded BHCs, except for those in Size 3 where a significantly positive coefficient of PUBLIC is found. In the right hand panel, firm size is found to have a negative effect on ROA volatility for the full sample, again indicating better diversification opportunities among larger firms. The size effect disappears after the sample firms are grouped into size classes. The loan-to-asset ratio has a significantly positive effect on ROA volatility for the full sample, and is marginally significant for the Size 1 regression, suggesting that higher loan concentration raises earnings volatility. Regarding portfolio composition, both C\&I lending and fee based activities are found to raise earnings volatility, while consumer lending tends to lower it. On the funding side, there is some evidence that relying on large $\mathrm{CD}$ funding tends to raise earnings volatility, as rates on large $\mathrm{CDs}$ fluctuate with market interest rates whereas rates on core deposits tend to be more stable. The coefficient of PUBLIC is insignificant in general but is significantly positive for Size 3 firms.

Results of estimating the SDROE regressions, presented in Table 6, are almost qualitatively identical to those of the SDROA regressions. Moreover, for robustness, using alternative computations of SDROA and SDROE that exclude tax and extraordinary items from calculating the returns provides qualitatively similar results. In summary, publicly traded BHCs and non-publicly traded BHCs exhibit very similar earnings volatility. Like the analysis of credit risk, there is some evidence that publicly traded BHCs in Size 3 actually have higher earnings volatility than otherwise similar non-publicly traded $\mathrm{BHCs}$, a finding that is in contradiction to the strong-form of market discipline being at work. 


\section{Capitalization}

Table 7 reports the results of estimating the CAPITAL regressions. In the left hand panel, firm size is found to have a significantly negative effect on bank capitalization, which is driven by larger BHCs in Size 1, suggesting that larger BHCs tend to hold less capital. However, the amount of capital between public and private BHCs is statistically indistinguishable. The results are very similar after controlling for differences in portfolio compositions, as evidenced in the right hand panel. Interestingly, the coefficient of the loan to asset ratio is significantly negative, indicating that BHCs that made more loans tend to hold less capital. Thus, rather than holding more capital against portfolio risk, it appears that BHCs that were more aggressive in lending were more aggressive in managing their capital holding. While concentration in C\&I lending does not seem to have any significant effects on capitalization, more consumer lending is found to be associated with higher capital. A negative relationship between the amount of core deposits and capital is also detected, perhaps because federally insured deposits may be less sensitive to bank risk. In sum, the findings show no significant difference in capitalization between publicly traded and privately owned BHCs.

\section{Failure Risk}

Table 8 reports the estimates of the Z-score regressions. Recall that banks with lower bankruptcy risk have higher Z-scores. In the left hand panel, firm size is found to have a significantly positive effect on Z-score, suggesting that large firms tend to have higher Z-scores, possibly due to the better diversification opportunities available to large firms. The size effect disappears in the size based regressions. Regarding the effect of public ownership on failure risk, the results are somewhat mixed. For the full sample, public ownership is found to have an 
insignificant effect on the Z-score. In the regression for Size 1 BHCs, the coefficient of PUBLIC is positive and marginally significant, while in the Size 3 regression, it has a significantly negative coefficient. In the right hand panel, higher loan to asset ratio is found to lower the Zscore, so does the higher concentrations in C\&I lending and fee based activities. On the other hand, higher concentration in consumer lending tends to raise the Z-score. On the liability side, using more large $\mathrm{CD}$ funding is found to lower the Z-score. Note that the effects of firm characteristics on the Z-score are broadly similar to their effects on credit risk and earnings volatility. However, the effect of public ownership on the Z-score remains somewhat mixed.

Table 9 reports the estimates of the BOPEC regressions. Note that unlike the ordering of the Z-score, BHCs with higher BOPEC ratings are associated with higher failure risk. In the left hand panel, firm size is found to have a negative effect on BOPEC rating for the full sample, but the size effect largely disappears after grouping the sample BHCs into size classes. Public ownership is found to have a significantly positive effect on the BOPEC rating. The result is fairly robust with respect to bank size, except for the largest size quartile. The findings indicate that publicly traded BHCs tend to have a higher BOPEC rating and hence higher failure risk than non-publicly traded BHCs. In the right hand panel, the loan to asset ratio, the fee ratio, and the large $\mathrm{CD}$ ratio are all found to have significantly positive effects on the BOPEC rating, while the consumer loan ratio and the core deposit ratio are found to reduce the BOPEC rating significantly. After controlling for portfolio composition and funding mix, publicly traded BHCs are found to have significantly higher numerical BOPEC ratings and hence higher failure risk than otherwise similar non-publicly traded BHCs. These findings reject the strong-form of market discipline that the availability of public market signals would lead to less bank risk- 
taking. ${ }^{13}$

\section{B. Same Firm Comparison}

Results of comparing the risk-taking of the same BHCs relative to their peers before and after they went public (or private) are presented in Table 10. The first column of Table 10 depicts the risk measure used in computing the CRR, i.e., the Change in Relative Risk. The second column reports the mean and the median CRR of all firms that went public or private. The t-statistic and the signed rank statistic testing whether the CRR is significantly different from zero are reported in the next two columns. The last column reports the number of CRRs being analyzed.

In Panel A, the CRRs are calculated using the mean difference in risk between each subject BHC and its peer. The mean and median CRR for both BADLOAN and CHARGEOFF are all positive, suggesting that on average the same BHC tends to have more bad loans and loan charge-offs when it was publicly traded than when it was privately held. In both cases, while the t-statistics are insignificant, the signed-rank statistics are significant at the $10 \%$ level. The mean and median CRR for CAPITAL are negative, indicating that on average the same BHC tends to hold less capital when it was publicly traded than when it was privately owned. Again, the tstatistic is insignificant but the signed-rank statistic is. Regarding the CRR for BOPEC, the mean and the median have opposite signs and both the t-statistic and the signed-rank statistic are insignificant.

13 The question of why do publicly traded BHCs tend to have worse supervisory ratings than otherwise similar privately owned BHCs is beyond the scope of this paper but definitely worthy of investigation. For example, does the availability of public market signals has anything to do with their worse BOPEC ratings? I leave these interesting questions for future research. 
In Panel B, the CRRs are computed using the median difference in risk between each subject BHC and its peer. The results are qualitatively similar but statistically stronger. The tstatistics for both CHARGEOFF and CAPITAL are significant at the 5\% level. The signed-rank statistics for BADLOAN, CHARGEOFF, and CAPITAL all increase in the level of significance. The findings in Panel B strongly suggest that the same BHC tends to have more asset risk while holding less capital when it was publicly traded than when it was privately owned, which is inconsistent with strong-form of market discipline at work.

In Panel C, the CRRs for SDROA, SDROE, and ZSCORE are reported. The mean and the median CRR for SDROA have opposite signs and the t-statistic is insignificant; however, the signed-rank statistic is significantly negative at the $5 \%$ level, suggesting that on average the ROA volatility is lower when the BHC was publicly traded than when it was privately held. Regarding the SDROE, both the mean and the median CRR are negative and the signed-rank statistic is significantly negative at the $1 \%$ level, again indicating that the volatility of ROE is lower when the $\mathrm{BHC}$ was public than when it was private. While the results seem to provide support to the strong-form of market discipline, they are also consistent with earnings management that is more likely to be practiced when the firm is public than when it was private. The CRR for ZSCORE is insignificant.

\section{Summary and Conclusions}

This paper tests the strong-form of market discipline that publicly traded banking organizations with constantly available market signals from their stock (and bond) prices would take less risk than otherwise similar non-publicly traded banks that do not have constant market 
signals. The source of market discipline comes from banks' counterparties, borrowers, and regulators who can costlessly observe, and respond to, those public market signals. Unlike nonpublicly traded banks that are completely immune from this kind of market discipline, the strongform of market discipline predicts that publicly traded banks tend to take less risk. In the regression analysis, I compare seven measures of bank risk between similar sized publicly traded and non-publicly traded BHCs, with and without controlling for portfolio compositions and funding fix. In the second set of analysis, I compare the risk-taking of the same BHC before and after it went public, relative to similar sized BHCs that did not went public or private over the sampling period.

The regression analysis does not detect any significant difference in credit risk, earnings volatility, and capital between otherwise similar public and private BHCs. However, the BOPEC regression do indicates that publicly traded BHCs tend to have worse supervisory ratings than non-publicly traded BHCs, which is inconsistent with the strong-form of market discipline.

Comparing the risk taking of the same BHCs before and after they went public indicates that BHCs tend to have higher asset risk and hold less capital when they were publicly traded than when they were privately held. The results reject the strong-form of market discipline. The same firm comparison also indicates that earnings volatility tends to be lower when the BHCs were public than when they were private. While this finding is consistent with the strong-form of market discipline, it is also consistent with earnings management.

Overall, the results in this paper reject the strong-form of market discipline. Not only does the availability of public market signals fail to constrain bank risk taking, the finding that publicly traded BHCs tend to take more risk seems an interesting area for future research. 


\section{References}

Bae, K.-H., J.-K. Kang, and C.-W.-Lim, 2002, The value of durable bank relationships: Evidence from Korean banking shocks, Journal of Financial Economics 64, 181-214.

Bliss, R. R. and M. J. Flannery, 2002, Market discipline in the governance of U.S. bank holding companies: Monitoring vs. influencing, European Finance Review 6 (3), 361-395.

Boyd, J. H. and S. L. Graham, 1988, The profitability and risk effects of allowing bank holding companies to merge with other financial firms: A simulation study, Federal Reserve Bank of Minneapolis Quarterly Review 12 (2), 3-20.

Diamond, D., 1991, Monitoring and reputation: The choice between banl loans and directly placed debt, Journal of Political Economy 99, 689-721.

Federal Reserve, 1999, Using subordinated debt as an instrument of market discipline, Federal Reserve Staff Study, Board of Governors of the Federal Reserve System.

Flannery, M. J., 1998, Using market information in prudential bank supervision: A review of the U.S. empirical evidence, Journal of Money, Credit, and Banking 30, 273-305.

Gibson, M.S., 1995, Can bank health affect investment? Evidence from Japan, Journal of Business 68, 281-308.

Greenspan, A., 2001, The financial safety net, Remarks to the 37th Annual Conference on Bank Structure and Competition of the Federal Reserve Bank of Chicago, Chicago, Illinois.

Kang, J.-K. and R. M. Stulz, 2000, Do banking shocks affect borrowing firm performance? An analysis of the Japanese experience, Journal of Business 73, 1-23.

Merton, R.C., 1974, On the pricing of corporate debt: The risk structure of interest rates, Journal of Finance 29, 449-470.

New Basel Capital Accord, 2003, Basel Committee on Banking Supervision, Bank for International Settlements, Basel, Switzerland.

Ramakrishnan, R. and A. Thakor, 1984, Information reliability and a theory of financial intermediation, Review of Economic Studies 52, 415-432.

Roy, A. D., 1952, Safety first and the holding of assets, Econometrica 20, 431-449.

Sharpe, S. A., 1990, Asymmetric information, bank lending, and implicit contracts: A stylized model of customer relationships, Journal of Finance 45, 1069-1087. 
Slovin, M. B., M. F. Sushka, and J. A. Polonchek, 1993, The value of bank durability: Borrowers and bank stakeholders, Journal of Finance 48, 247-266.

Smith, C.W. and J. B. Warner, 1979, On financial contracting: An analysis of bond covenants, Journal of Financial Economics 7, 117-161. 


\section{Table 1: Summary Statistics of Publicly Traded and Privately Held Banking Companies}

This table shows the sample mean and median (in parentheses) total assets, loan-to-asset ratio, ratio of commercial and industrial (C\&I) loans to total loans, ratio of consumer loans to total loans, ratio of fee income to total income, ratio of core deposits to total assets, and ratio of large CDs to total assets of publicly traded and privately held BHCs by size class from 1986 to 2001 . Size 1 contains the largest firms.

\begin{tabular}{|c|c|c|c|c|c|c|c|c|}
\hline & \multicolumn{2}{|c|}{ Size 1 } & \multicolumn{2}{c|}{ Size 2 } & \multicolumn{2}{c|}{ Size 3 } & \multicolumn{2}{c|}{ Size 4 } \\
\cline { 2 - 8 } & Public & Private & Public & Private & Public & Private & Public & Private \\
\hline $\begin{array}{c}\text { Total assets } \\
\text { (in \$ millions) }\end{array}$ & $\begin{array}{c}\$ 2,145.4 \\
(\$ 1,491.3)\end{array}$ & $\begin{array}{c}\$ 1,118.9 \\
(\$ 778.0)\end{array}$ & $\begin{array}{c}\$ 451.3 \\
(\$ 442.6)\end{array}$ & $\begin{array}{c}\$ 420.8 \\
(\$ 413.1)\end{array}$ & $\begin{array}{c}\$ 293.3 \\
(\$ 290.6)\end{array}$ & $\begin{array}{c}\$ 270.8 \\
(\$ 267.1)\end{array}$ & $\begin{array}{c}\$ 197.3 \\
(\$ 201.1)\end{array}$ & $\begin{array}{c}\$ 188.0 \\
(\$ 187.5)\end{array}$ \\
\hline $\begin{array}{c}\text { Total loans to } \\
\text { total assets }\end{array}$ & $\begin{array}{c}62.4 \% \\
(63.4 \%)\end{array}$ & $\begin{array}{c}59.3 \% \\
(61.0 \%)\end{array}$ & $\begin{array}{c}63.8 \% \\
(65.1 \%)\end{array}$ & $\begin{array}{c}59.8 \% \\
(60.8 \%)\end{array}$ & $\begin{array}{c}63.8 \% \\
(64.6 \%)\end{array}$ & $\begin{array}{c}59.4 \% \\
(60.7 \%)\end{array}$ & $\begin{array}{c}64.0 \% \\
(64.0 \%)\end{array}$ & $\begin{array}{c}58.1 \% \\
(59.3 \%)\end{array}$ \\
\hline $\begin{array}{c}\text { C\&I loans to } \\
\text { total loans }\end{array}$ & $\begin{array}{c}20.8 \% \\
(18.8 \%)\end{array}$ & $\begin{array}{c}21.4 \% \\
(19.6 \%)\end{array}$ & $\begin{array}{c}19.9 \% \\
(17.5 \%)\end{array}$ & $\begin{array}{c}20.1 \% \\
(18.2 \%)\end{array}$ & $\begin{array}{c}19.7 \% \\
(17.8 \%)\end{array}$ & $\begin{array}{c}19.5 \% \\
(17.0 \%)\end{array}$ & $\begin{array}{c}21.0 \% \\
(18.3 \%)\end{array}$ & $\begin{array}{c}18.7 \% \\
(16.8 \%)\end{array}$ \\
\hline $\begin{array}{c}\text { Consumer loans } \\
\text { to total loans }\end{array}$ & $\begin{array}{c}18.2 \% \\
(17.2 \%)\end{array}$ & $\begin{array}{c}16.5 \% \\
(13.7 \%)\end{array}$ & $\begin{array}{c}14.0 \% \\
(11.7 \%)\end{array}$ & $\begin{array}{c}15.5 \% \\
(13.5 \%)\end{array}$ & $\begin{array}{c}13.7 \% \\
(10.7 \%)\end{array}$ & $\begin{array}{c}15.5 \% \\
(13.3 \%)\end{array}$ & $\begin{array}{c}12.7 \% \\
(9.8 \%)\end{array}$ & $\begin{array}{c}16.0 \% \\
(14.1 \%)\end{array}$ \\
\hline $\begin{array}{c}\text { Fee income to } \\
\text { total income }\end{array}$ & $\begin{array}{c}12.1 \% \\
(11.3 \%)\end{array}$ & $\begin{array}{c}12.7 \% \\
(11.2 \%)\end{array}$ & $\begin{array}{c}10.5 \% \\
(9.6 \%)\end{array}$ & $\begin{array}{c}11.2 \% \\
(10.0 \%)\end{array}$ & $\begin{array}{c}10.9 \% \\
(10.3 \%)\end{array}$ & $\begin{array}{c}10.3 \% \\
(9.2 \%)\end{array}$ & $\begin{array}{c}8.9 \% \\
(8.6 \%)\end{array}$ & $\begin{array}{c}9.6 \% \\
(8.7 \%)\end{array}$ \\
\hline $\begin{array}{c}\text { Core deposits to } \\
\text { total assets }\end{array}$ & $\begin{array}{c}37.1 \% \\
(36.4 \%)\end{array}$ & $\begin{array}{c}37.2 \% \\
(37.2 \%)\end{array}$ & $\begin{array}{c}37.4 \% \\
(35.9 \%)\end{array}$ & $\begin{array}{c}35.7 \% \\
(34.8 \%)\end{array}$ & $\begin{array}{c}36.7 \% \\
(35.2 \%)\end{array}$ & $\begin{array}{c}34.2 \% \\
(33.4 \%)\end{array}$ & $\begin{array}{c}35 \% \\
(34.5 \%)\end{array}$ & $\begin{array}{c}32.8 \% \\
(31.8 \%)\end{array}$ \\
\hline $\begin{array}{c}\text { Large CDs to } \\
\text { total assets }\end{array}$ & $\begin{array}{c}9.6 \% \\
(8.3 \%)\end{array}$ & $\begin{array}{c}10.5 \% \\
(8.9 \%)\end{array}$ & $\begin{array}{c}10.2 \% \\
(9.6 \%)\end{array}$ & $\begin{array}{c}9.9 \% \\
(8.7 \%)\end{array}$ & $\begin{array}{c}9.8 \% \\
(9.1 \%)\end{array}$ & $\begin{array}{c}10.6 \% \\
(9.4 \%)\end{array}$ & $\begin{array}{c}10.7 \% \\
(10.3 \%)\end{array}$ & $\begin{array}{c}10.1 \% \\
(9.1 \%)\end{array}$ \\
\hline N & 1812 & 986 & 520 & 1471 & 347 & 2445 & 149 & 3091 \\
\hline
\end{tabular}




\section{Table 2: Descriptive Statistics of Bank Risk}

This table reports the mean (median) of seven bank risk measures: BADLOAN is the ratio of past due and nonaccural loans to total loans; CHARGEOFF is the ratio of net charge-offs to total loans; SDROA is the standard deviation of return on assets; SDROE is the standard deviation of return on equity; CAPITAL is the equity to asset ratio; Z-SCORE measures bank failure risk; and BOPEC is the confidential supervisory rating of bank safety and soundness. The Wilcoxon $Z$ derived from the Rank Sum test, with the p-value in parentheses, is computed for the smaller sample, i.e., the private sample for Size 1 and the public sample for Size 2, 3, and 4. Size 1 contains the largest firms.

\begin{tabular}{|c|c|c|c|}
\hline \multicolumn{4}{|c|}{ BADLOAN } \\
\hline Size Class & Public (in \%) & Private (in \%) & Wilcoxon Z \\
\hline 1 & $\begin{array}{c}1.35 \\
(0.89)\end{array}$ & $\begin{array}{c}1.33 \\
(0.90)\end{array}$ & $\begin{array}{l}-1.2753 \\
(0.2022)\end{array}$ \\
\hline 2 & $\begin{array}{c}1.22 \\
(0.77)\end{array}$ & $\begin{array}{r}1.29 \\
(0.89) \\
\end{array}$ & $\begin{array}{l}-2.1057 * * \\
(0.0352)\end{array}$ \\
\hline 3 & $\begin{array}{r}1.50 \\
(0.91)\end{array}$ & $\begin{array}{r}1.39 \\
(0.89) \\
\end{array}$ & $\begin{array}{r}0.3810 \\
(0.7032) \\
\end{array}$ \\
\hline 4 & $\begin{array}{c}1.27 \\
(0.81) \\
\end{array}$ & $\begin{array}{c}1.34 \\
(0.85)\end{array}$ & $\begin{array}{l}-0.3877 \\
(0.6982) \\
\end{array}$ \\
\hline \multicolumn{4}{|c|}{ CHARGEOFF } \\
\hline Size Class & Public (in \%) & Private (in \%) & Wilcoxon Z \\
\hline 1 & $\begin{array}{c}0.61 \\
(0.40) \\
\end{array}$ & $\begin{array}{c}0.66 \\
(0.36) \\
\end{array}$ & $\begin{array}{c}-3.0182 * * * \\
(0.0025)\end{array}$ \\
\hline 2 & $\begin{array}{r}0.46 \\
(0.29) \\
\end{array}$ & $\begin{array}{r}0.52 \\
(0.31) \\
\end{array}$ & $\begin{array}{l}-1.1527 \\
(0.2490) \\
\end{array}$ \\
\hline 3 & $\begin{array}{c}0.62 \\
(0.32) \\
\end{array}$ & $\begin{array}{c}0.55 \\
(0.30) \\
\end{array}$ & $\begin{array}{c}0.9699 \\
(0.3321) \\
\end{array}$ \\
\hline 4 & $\begin{array}{c}0.66 \\
(0.30)\end{array}$ & $\begin{array}{c}0.55 \\
(0.31)\end{array}$ & $\begin{array}{c}0.2375 \\
(0.8122)\end{array}$ \\
\hline \multicolumn{4}{|c|}{ SDROA } \\
\hline Size Class & Public (in \%) & Private (in \%) & Wilcoxon Z \\
\hline 1 & $\begin{array}{c}0.12 \\
(0.08)\end{array}$ & $\begin{array}{c}0.11 \\
(0.08) \\
\end{array}$ & $\begin{array}{l}-0.0606 \\
(0.9517)\end{array}$ \\
\hline 2 & $\begin{array}{c}0.16 \\
(0.06)\end{array}$ & $\begin{array}{c}0.14 \\
(0.08)\end{array}$ & $\begin{array}{l}-0.1809 \\
(0.8564)\end{array}$ \\
\hline 3 & $\begin{array}{c}0.18 \\
(0.19)\end{array}$ & $\begin{array}{c}0.16 \\
(0.08)\end{array}$ & $\begin{array}{c}1.6025 \\
(0.1090)\end{array}$ \\
\hline 4 & $\begin{array}{r}0.22 \\
(0.07) \\
\end{array}$ & $\begin{array}{c}0.09 \\
(0.06) \\
\end{array}$ & $\begin{array}{r}0.7006 \\
(0.4835) \\
\end{array}$ \\
\hline
\end{tabular}




\begin{tabular}{|c|c|c|c|}
\hline \multicolumn{4}{|c|}{ SDROE } \\
\hline Size Class & Public (in \%) & Private (in \%) & Wilcoxon Z \\
\hline 1 & $\begin{array}{c}1.98 \\
(0.90)\end{array}$ & $\begin{array}{c}1.39 \\
(0.97)\end{array}$ & $\begin{array}{c}0.4326 \\
(0.6653) \\
\end{array}$ \\
\hline 2 & $\begin{array}{c}2.38 \\
(1.07) \\
\end{array}$ & $\begin{array}{c}2.25 \\
(0.76)\end{array}$ & $\begin{array}{c}0.1480 \\
(0.8823)\end{array}$ \\
\hline 3 & $\begin{array}{c}2.58 \\
(2.67)\end{array}$ & $\begin{array}{c}3.15 \\
(1.15)\end{array}$ & $\begin{array}{l}1.5088 \\
(0.1314)\end{array}$ \\
\hline 4 & $\begin{array}{c}2.63 \\
(0.88) \\
\end{array}$ & $\begin{array}{c}1.09 \\
(0.74) \\
\end{array}$ & $\begin{array}{c}0.6351 \\
(0.5254) \\
\end{array}$ \\
\hline \multicolumn{4}{|c|}{ CAPITAL } \\
\hline Size Class & Public (in \%) & Private (in \%) & Wilcoxon Z \\
\hline 1 & $\begin{array}{c}8.05 \\
(7.94) \\
\end{array}$ & $\begin{array}{c}8.06 \\
(7.85) \\
\end{array}$ & $\begin{array}{l}-1.1412 \\
(0.2538) \\
\end{array}$ \\
\hline 2 & $\begin{array}{c}8.53 \\
(8.43)\end{array}$ & $\begin{array}{c}8.44 \\
(8.27)\end{array}$ & $\begin{array}{c}1.2770 \\
(0.2016)\end{array}$ \\
\hline 3 & $\begin{array}{c}8.61 \\
(8.69) \\
\end{array}$ & $\begin{array}{r}8.22 \\
(8.07) \\
\end{array}$ & $\begin{array}{l}4.2188 * * * \\
(<0.0001)\end{array}$ \\
\hline 4 & $\begin{array}{r}9.06 \\
(8.88) \\
\end{array}$ & $\begin{array}{c}8.57 \\
(8.44) \\
\end{array}$ & $\begin{array}{l}2.0541 * * \\
(0.0400) \\
\end{array}$ \\
\hline \multicolumn{4}{|c|}{$\overline{\bar{Z}}$} \\
\hline Size Class & Public & Private & Wilcoxon $\mathrm{Z}$ \\
\hline 1 & $\begin{array}{c}127.88 \\
(107.45)\end{array}$ & $\begin{array}{l}116.27 \\
(97.51) \\
\end{array}$ & $\begin{array}{l}-0.3031 \\
(0.7618) \\
\end{array}$ \\
\hline 2 & $\begin{array}{c}146.33 \\
(100.56)\end{array}$ & $\begin{array}{c}135.39 \\
(130.08)\end{array}$ & $\begin{array}{l}-0.0164 \\
(0.9869)\end{array}$ \\
\hline 3 & $\begin{array}{c}91.68 \\
(40.39)\end{array}$ & $\begin{array}{l}103.27 \\
(84.90)\end{array}$ & $\begin{array}{l}-1.5275 \\
(0.1266)\end{array}$ \\
\hline 4 & $\begin{array}{r}140.47 \\
(119.99) \\
\end{array}$ & $\begin{array}{c}172.00 \\
(142.27) \\
\end{array}$ & $\begin{array}{l}-0.8235 \\
(0.4102)\end{array}$ \\
\hline \multicolumn{4}{|c|}{$\overline{\text { BOPEC }}$} \\
\hline Size Class & Public & Private & Wilcoxon Z \\
\hline 1 & $\begin{array}{l}1.72 \\
(2.00)\end{array}$ & $\begin{array}{c}1.72 \\
(2.00)\end{array}$ & $\begin{array}{c}0.8646 \\
(0.3873)\end{array}$ \\
\hline 2 & $\begin{array}{c}1.74 \\
(2.00)\end{array}$ & $\begin{array}{c}1.69 \\
(2.00)\end{array}$ & $\begin{array}{l}1.8908 * \\
(0.0586)\end{array}$ \\
\hline 3 & $\begin{array}{c}1.93 \\
(2.00) \\
\end{array}$ & $\begin{array}{c}1.78 \\
(2.00) \\
\end{array}$ & $\begin{array}{c}2.6597 * * * \\
(0.0078)\end{array}$ \\
\hline 4 & $\begin{array}{c}2.07 \\
(2.00)\end{array}$ & $\begin{array}{c}1.74 \\
(2.00)\end{array}$ & $\begin{array}{c}4.7534 * * * \\
(<0.0001)\end{array}$ \\
\hline
\end{tabular}

$* * *, * *, *$ indicate significance at the $1 \%, 5 \%$, and $10 \%$ level, respectively. 
Table 3: Comparing Non-Performing Loans between Publicly Traded and Non-Publicly Traded Banking Organizations

BADLOAN (ratio of past due and nonaccural loans to total loans) is regressed on public ownership dummy, firm characteristics, timeeffect dummies (not reported), and Federal Reserve District dummies (not reported). Robust t-statistics are in parentheses.

\begin{tabular}{|c|c|c|c|c|c|c|c|c|c|c|}
\hline & All Obs. & Size 1 & Size 2 & Size 3 & Size 4 & All Obs. & Size 1 & Size 2 & Size 3 & Size 4 \\
\hline $\begin{array}{l}\text { Public } \\
\text { ownership }\end{array}$ & $\begin{array}{c}0.02 \\
(0.38)\end{array}$ & $\begin{array}{c}0.04 \\
(0.44)\end{array}$ & $\begin{array}{c}0.03 \\
(0.27)\end{array}$ & $\begin{array}{l}0.22 \\
(1.60)\end{array}$ & $\begin{array}{l}-0.04 \\
(-0.28)\end{array}$ & $\begin{array}{c}0.03 \\
(0.596)\end{array}$ & $\begin{array}{l}0.09 \\
(0.92)\end{array}$ & $\begin{array}{l}0.002 \\
(0.02)\end{array}$ & $\begin{array}{l}0.18 \\
(1.36)\end{array}$ & $\begin{array}{l}-0.12 \\
(-0.77)\end{array}$ \\
\hline $\begin{array}{l}\text { Log of total } \\
\text { assets }\end{array}$ & $\begin{array}{l}-0.05 \\
(-1.51)\end{array}$ & $\begin{array}{c}0.01 \\
(0.15)\end{array}$ & $\begin{array}{l}0.16 \\
(0.61)\end{array}$ & $\begin{array}{l}-0.25 \\
(-0.78)\end{array}$ & $\begin{array}{l}0.16 \\
(0.66)\end{array}$ & $\begin{array}{c}-0.08 * * * \\
(-2.61)\end{array}$ & $\begin{array}{l}-0.03 \\
(-0.48)\end{array}$ & $\begin{array}{l}0.13 \\
(0.52)\end{array}$ & $\begin{array}{l}-0.32 \\
(-1.06)\end{array}$ & $\begin{array}{c}-0.07 \\
(-0.39)\end{array}$ \\
\hline $\begin{array}{l}\text { Total loans to } \\
\text { total assets }\end{array}$ & & & & & & $\begin{array}{c}0.13 \\
(0.57)\end{array}$ & $\begin{array}{l}0.70 * \\
(1.73)\end{array}$ & $\begin{array}{c}0.61 \\
(1.36)\end{array}$ & $\begin{array}{c}0.16 \\
(0.39)\end{array}$ & $\begin{array}{c}-0.53 \\
(-1.49)\end{array}$ \\
\hline $\begin{array}{l}\text { C\&I loans to } \\
\text { total loans }\end{array}$ & & & & & & $\begin{array}{l}0.47 * \\
(1.69)\end{array}$ & $\begin{array}{l}0.003 \\
(0.01)\end{array}$ & $\begin{array}{c}0.40 \\
(0.73)\end{array}$ & $\begin{array}{c}0.38 \\
(0.81)\end{array}$ & $\begin{array}{l}1.07 * \\
(1.94)\end{array}$ \\
\hline $\begin{array}{l}\text { Consumer loans } \\
\text { to total loans }\end{array}$ & & & & & & $\begin{array}{c}-1.88 * * * \\
(-6.48)\end{array}$ & $\begin{array}{c}-1.46 * * * \\
(-3.14)\end{array}$ & $\begin{array}{c}-2.07 * * * \\
(-3.32)\end{array}$ & $\begin{array}{c}-2.14 * * * \\
(-5.12)\end{array}$ & $\begin{array}{c}-2.04 * * * \\
(-5.21)\end{array}$ \\
\hline $\begin{array}{l}\text { Fee income to } \\
\text { total income }\end{array}$ & & & & & & $\begin{array}{c}2.52 * * * \\
(5.20)\end{array}$ & $\begin{array}{c}2.09 * * * \\
(3.12)\end{array}$ & $\begin{array}{l}0.54 \\
(0.68)\end{array}$ & $\begin{array}{c}3.35 * * * \\
(4.65)\end{array}$ & $\begin{array}{c}3.47 * * * \\
(3.59)\end{array}$ \\
\hline $\begin{array}{l}\text { Core deposits to } \\
\text { total assets }\end{array}$ & & & & & & $\begin{array}{c}0.24 \\
(0.89)\end{array}$ & $\begin{array}{c}0.69 \\
(1.60)\end{array}$ & $\begin{array}{c}-0.43 \\
(-0.85)\end{array}$ & $\begin{array}{l}-0.36 \\
(-0.72)\end{array}$ & $\begin{array}{l}0.51 \\
(1.14)\end{array}$ \\
\hline $\begin{array}{l}\text { Large CDs to } \\
\text { total assets }\end{array}$ & & & & & & $\begin{array}{c}3.08 * * * \\
(5.80)\end{array}$ & $\begin{array}{c}3.57 * * * \\
(4.21)\end{array}$ & $\begin{array}{l}2.51 * * \\
(2.47)\end{array}$ & $\begin{array}{l}2.02 * * \\
(2.14)\end{array}$ & $\begin{array}{c}3.66 * * * \\
(3.51)\end{array}$ \\
\hline $\mathrm{R}^{2}$ & 0.18 & 0.22 & 0.15 & 0.2 & 0.2 & 0.21 & 0.26 & 0.19 & 0.23 & 0.25 \\
\hline $\mathrm{N}$ & 10819 & 2798 & 1989 & 2792 & 3240 & 10819 & 2798 & 1989 & 2792 & 3240 \\
\hline
\end{tabular}

$* * *, * *, *$ indicate significance at the $1 \%, 5 \%$, and $10 \%$ level, respectively. 


\section{Table 4: Comparing Net Charge-offs between Publicly Traded and Non-Publicly Traded Banking Organizations}

CHARGEOFF (ratio of net charge-offs to total loans) is regressed on public dummy, firm characteristics, time-effect dummies Not reported), and Federal Reserve District dummies (not reported). Robust t-statistics are in parentheses.

\begin{tabular}{|c|c|c|c|c|c|c|c|c|c|c|}
\hline & All Obs. & Size 1 & Size 2 & Size 3 & Size 4 & All Obs. & Size 1 & Size 2 & Size 3 & Size 4 \\
\hline $\begin{array}{l}\text { Public } \\
\text { ownership }\end{array}$ & $\begin{array}{c}0.05 \\
(1.30)\end{array}$ & $\begin{array}{c}0.03 \\
(0.41)\end{array}$ & $\begin{array}{c}0.03 \\
(0.74)\end{array}$ & $\begin{array}{l}0.18 * * \\
(2.40)\end{array}$ & $\begin{array}{c}0.14 \\
(1.32)\end{array}$ & $\begin{array}{c}0.05 \\
(1.41)\end{array}$ & $\begin{array}{c}0.02 \\
(0.24)\end{array}$ & $\begin{array}{c}0.02 \\
(0.50)\end{array}$ & $\begin{array}{l}0.15^{* *} \\
(2.00)\end{array}$ & $\begin{array}{c}0.13 \\
(1.34)\end{array}$ \\
\hline $\begin{array}{l}\text { Log of total } \\
\text { assets }\end{array}$ & $\begin{array}{c}0.02 \\
(0.95)\end{array}$ & $\begin{array}{c}0.03 \\
(0.57)\end{array}$ & $\begin{array}{c}0.21 \\
(1.44)\end{array}$ & $\begin{array}{c}-0.17 \\
(-1.23)\end{array}$ & $\begin{array}{l}-0.08 \\
(-0.66)\end{array}$ & $\begin{array}{l}-0.04 * \\
(-1.71)\end{array}$ & $\begin{array}{c}-0.06 \\
(-0.89)\end{array}$ & $\begin{array}{c}0.14 \\
(1.02)\end{array}$ & $\begin{array}{l}-0.21 \\
(-1.62)\end{array}$ & $\begin{array}{l}-0.20^{*} \\
(-1.71)\end{array}$ \\
\hline $\begin{array}{l}\text { Total loans to } \\
\text { total assets }\end{array}$ & & & & & & $\begin{array}{c}0.13 \\
(0.95)\end{array}$ & $\begin{array}{c}0.49 \\
(1.47)\end{array}$ & $\begin{array}{c}0.23 \\
(1.15)\end{array}$ & $\begin{array}{l}-0.002 \\
(-0.01)\end{array}$ & $\begin{array}{l}-0.15 \\
(-1.00)\end{array}$ \\
\hline $\begin{array}{l}\text { C\&I loans to } \\
\text { total loans }\end{array}$ & & & & & & $\begin{array}{c}0.59 * * * \\
(3.46)\end{array}$ & $\begin{array}{c}-0.08 \\
(-0.27)\end{array}$ & $\begin{array}{c}0.62 * * \\
(2.27)\end{array}$ & $\begin{array}{c}0.95 * * * \\
(3.83)\end{array}$ & $\begin{array}{c}0.91 * * * \\
(3.18)\end{array}$ \\
\hline $\begin{array}{l}\text { Consumer loans } \\
\text { to total loans }\end{array}$ & & & & & & $\begin{array}{l}0.91 * * \\
(2.24)\end{array}$ & $\begin{array}{l}1.89 * * \\
(2.29)\end{array}$ & $\begin{array}{c}0.83 \\
(1.58)\end{array}$ & $\begin{array}{c}0.29 \\
(1.49)\end{array}$ & $\begin{array}{c}0.18 \\
(0.85)\end{array}$ \\
\hline $\begin{array}{l}\text { Fee income to } \\
\text { total income }\end{array}$ & & & & & & $\begin{array}{c}2.88 * * * \\
(2.72)\end{array}$ & $\begin{array}{l}4.95 * * \\
(2.01)\end{array}$ & $\begin{array}{l}2.27 * \\
(1.77)\end{array}$ & $\begin{array}{c}1.41 * * * \\
(3.36)\end{array}$ & $\begin{array}{c}2.31 * * * \\
(3.03)\end{array}$ \\
\hline $\begin{array}{l}\text { Core deposits to } \\
\text { total assets }\end{array}$ & & & & & & $\begin{array}{c}-0.24 \\
(-1.36)\end{array}$ & $\begin{array}{l}-0.36 \\
(-0.99)\end{array}$ & $\begin{array}{c}-0.41 \\
(-1.45)\end{array}$ & $\begin{array}{l}-0.35 \\
(-1.43)\end{array}$ & $\begin{array}{c}-0.18 \\
(-0.82)\end{array}$ \\
\hline $\begin{array}{l}\text { Large CDs to } \\
\text { total assets }\end{array}$ & & & & & & $\begin{array}{c}1.44 * * * \\
(3.27)\end{array}$ & $\begin{array}{c}2.77 * * \\
(2.56)\end{array}$ & $\begin{array}{c}1.24 * * * \\
(2.68)\end{array}$ & $\begin{array}{c}0.52 \\
(1.01)\end{array}$ & $\begin{array}{l}0.86 * * \\
(2.15)\end{array}$ \\
\hline $\mathrm{R}^{2}$ & 0.14 & 0.11 & 0.15 & 0.2 & 0.2 & 0.19 & 0.24 & 0.21 & 0.22 & 0.24 \\
\hline $\mathrm{N}$ & 10820 & 2798 & 1991 & 2792 & 3239 & 10820 & 2798 & 1991 & 2792 & 3239 \\
\hline
\end{tabular}

$* * *, * *, *$ indicate significance at the $1 \%, 5 \%$, and $10 \%$ level, respectively. 


\section{Table 5: Comparing ROA Volatilities between Publicly Traded and Non-Publicly Traded Banking Organizations}

SDROA (standard deviation of ROA) is regressed on public dummy, firm characteristics, time-effect dummies (not reported), and Federal Reserve District dummies (not reported). Robust t-statistics are in parentheses.

\begin{tabular}{|c|c|c|c|c|c|c|c|c|c|c|}
\hline & All Obs. & Size 1 & Size 2 & Size 3 & Size 4 & All Obs. & Size 1 & Size 2 & Size 3 & Size 4 \\
\hline $\begin{array}{l}\text { Public } \\
\text { ownership }\end{array}$ & $\begin{array}{c}0.01 \\
(1.12)\end{array}$ & $\begin{array}{l}-0.004 \\
(-0.23)\end{array}$ & $\begin{array}{l}0.004 \\
(0.15)\end{array}$ & $\begin{array}{c}0.06 * * * \\
(2.71)\end{array}$ & $\begin{array}{c}0.04 \\
(1.31)\end{array}$ & $\begin{array}{c}0.01 \\
(1.09)\end{array}$ & $\begin{array}{l}0.0002 \\
(0.01)\end{array}$ & $\begin{array}{l}-0.004 \\
(-0.19)\end{array}$ & $\begin{array}{l}0.06^{* * *} \\
(2.45)\end{array}$ & $\begin{array}{c}0.04 \\
(1.52)\end{array}$ \\
\hline $\begin{array}{l}\text { Log of total } \\
\text { assets }\end{array}$ & $\begin{array}{c}-0.01 \\
(-1.61)\end{array}$ & $\begin{array}{l}-0.004 \\
(-0.28)\end{array}$ & $\begin{array}{c}-0.02 \\
(-0.27)\end{array}$ & $\begin{array}{c}-0.08 \\
(-1.23)\end{array}$ & $\begin{array}{l}-0.05 \\
(-1.31)\end{array}$ & $\begin{array}{c}-0.02 * * * \\
(-2.76)\end{array}$ & $\begin{array}{l}-0.01 \\
(-0.72)\end{array}$ & $\begin{array}{l}-0.001 \\
(-0.01)\end{array}$ & $\begin{array}{l}-0.10 \\
(-1.52)\end{array}$ & $\begin{array}{c}-0.04 \\
(-1.27)\end{array}$ \\
\hline $\begin{array}{l}\text { Total loans to } \\
\text { total assets }\end{array}$ & & & & & & $\begin{array}{c}0.08 * * * \\
(2.91)\end{array}$ & $\begin{array}{l}0.08 * \\
(1.78)\end{array}$ & $\begin{array}{c}0.06 \\
(0.83)\end{array}$ & $\begin{array}{c}0.08 \\
(1.27)\end{array}$ & $\begin{array}{c}0.06 \\
(1.22)\end{array}$ \\
\hline $\begin{array}{l}\text { C\&I loans to } \\
\text { total loans }\end{array}$ & & & & & & $\begin{array}{l}0.10 * * \\
(2.48)\end{array}$ & $\begin{array}{c}-0.04 \\
(-0.79)\end{array}$ & $\begin{array}{l}0.17 * * \\
(2.54)\end{array}$ & $\begin{array}{l}0.24^{*} \\
(1.82)\end{array}$ & $\begin{array}{l}0.12 * \\
(1.86)\end{array}$ \\
\hline $\begin{array}{l}\text { Consumer loans } \\
\text { to total loans }\end{array}$ & & & & & & $\begin{array}{l}-0.08^{*} \\
(-1.93)\end{array}$ & $\begin{array}{l}-0.13 * * \\
(-2.26)\end{array}$ & $\begin{array}{l}-0.006 \\
(-0.07)\end{array}$ & $\begin{array}{c}0.05 \\
(0.38)\end{array}$ & $\begin{array}{l}-0.15 * * \\
(-2.42)\end{array}$ \\
\hline $\begin{array}{l}\text { Fee income to } \\
\text { total income }\end{array}$ & & & & & & $\begin{array}{c}0.30 * * * \\
(3.76)\end{array}$ & $\begin{array}{l}0.40^{* * *} \\
(2.58)\end{array}$ & $\begin{array}{c}0.15 \\
(1.56)\end{array}$ & $\begin{array}{l}0.27 * * \\
(2.47)\end{array}$ & $\begin{array}{c}0.34 * * * \\
(2.69)\end{array}$ \\
\hline $\begin{array}{l}\text { Core deposits to } \\
\text { total assets }\end{array}$ & & & & & & $\begin{array}{c}0.05 \\
(1.19)\end{array}$ & $\begin{array}{c}0.02 \\
(0.24)\end{array}$ & $\begin{array}{c}0.13 \\
(1.50)\end{array}$ & $\begin{array}{l}-0.14 \\
(-1.18)\end{array}$ & $\begin{array}{l}0.14 * * \\
(2.17)\end{array}$ \\
\hline $\begin{array}{l}\text { Large CDs to } \\
\text { total assets }\end{array}$ & & & & & & $\begin{array}{l}0.16^{* *} \\
(2.39)\end{array}$ & $\begin{array}{c}0.13 \\
(1.04)\end{array}$ & $\begin{array}{c}0.01 \\
(0.08)\end{array}$ & $\begin{array}{c}0.18 \\
(1.34)\end{array}$ & $\begin{array}{l}0.32 * * \\
(2.33)\end{array}$ \\
\hline $\mathrm{R}^{2}$ & 0.08 & 0.11 & 0.13 & 0.15 & 0.09 & 0.12 & 0.15 & 0.18 & 0.21 & 0.18 \\
\hline $\mathrm{N}$ & 1464 & 477 & 234 & 316 & 437 & 1464 & 477 & 234 & 316 & 437 \\
\hline
\end{tabular}

$* * *, * *, *$ indicate significance at the $1 \%, 5 \%$, and $10 \%$ level, respectively. 


\section{Table 6: Comparing ROE Volatilities between Publicly Traded and Non-Publicly Traded Banking Organizations}

SDROE (standard deviation of ROE) is regressed on public dummy, firm characteristics, time-effect dummies (not reported), and Federal Reserve District dummies (not reported). Robust t-statistics are in parentheses.

\begin{tabular}{|c|c|c|c|c|c|c|c|c|c|c|}
\hline & All Obs. & Size 1 & Size 2 & Size 3 & Size 4 & All Obs. & Size 1 & Size 2 & Size 3 & Size 4 \\
\hline $\begin{array}{l}\text { Public } \\
\text { ownership }\end{array}$ & $\begin{array}{c}0.64 \\
(1.37)\end{array}$ & $\begin{array}{c}0.97 \\
(0.99)\end{array}$ & $\begin{array}{c}-0.02 \\
(-0.04)\end{array}$ & $\begin{array}{l}1.48 * * \\
(2.02)\end{array}$ & $\begin{array}{c}0.53 \\
(1.04)\end{array}$ & $\begin{array}{c}0.62 \\
(1.29)\end{array}$ & $\begin{array}{c}1.32 \\
(1.12)\end{array}$ & $\begin{array}{c}-0.23 \\
(-0.48)\end{array}$ & $\begin{array}{l}1.33 * \\
(1.69)\end{array}$ & $\begin{array}{c}0.53 \\
(1.27)\end{array}$ \\
\hline $\begin{array}{l}\text { Log of total } \\
\text { assets }\end{array}$ & $\begin{array}{c}-0.09 \\
(-0.62)\end{array}$ & $\begin{array}{l}-0.40 \\
(-0.57)\end{array}$ & $\begin{array}{c}0.17 \\
(0.10)\end{array}$ & $\begin{array}{c}-2.07 \\
(-1.24)\end{array}$ & $\begin{array}{l}-1.61 * \\
(-1.88)\end{array}$ & $\begin{array}{l}-0.29 * \\
(-1.73)\end{array}$ & $\begin{array}{c}-0.68 \\
(-0.86)\end{array}$ & $\begin{array}{c}0.50 \\
(0.32)\end{array}$ & $\begin{array}{l}-2.53 \\
(-1.41)\end{array}$ & $\begin{array}{l}-1.44 * \\
(-1.86)\end{array}$ \\
\hline $\begin{array}{l}\text { Total loans to } \\
\text { total assets }\end{array}$ & & & & & & $\begin{array}{c}3.09 * * * \\
(2.71)\end{array}$ & $\begin{array}{c}1.80 \\
(0.67)\end{array}$ & $\begin{array}{l}2.90 * \\
(1.71)\end{array}$ & $\begin{array}{c}5.34 \\
(1.47)\end{array}$ & $\begin{array}{c}2.14 * * \\
(2.32)\end{array}$ \\
\hline $\begin{array}{l}\text { C\&I loans to } \\
\text { total loans }\end{array}$ & & & & & & $\begin{array}{c}0.76 \\
(0.86)\end{array}$ & $\begin{array}{l}-2.76 \\
(-1.28)\end{array}$ & $\begin{array}{c}2.72 * * \\
(1.99)\end{array}$ & $\begin{array}{c}3.27 \\
(1.63)\end{array}$ & $\begin{array}{c}1.40 \\
(1.10)\end{array}$ \\
\hline $\begin{array}{l}\text { Consumer loans } \\
\text { to total loans }\end{array}$ & & & & & & $\begin{array}{l}-1.93 \\
(-1.47)\end{array}$ & $\begin{array}{l}-4.49 * \\
(-1.66)\end{array}$ & $\begin{array}{l}-1.30 \\
(-0.76)\end{array}$ & $\begin{array}{c}3.06 \\
(0.74)\end{array}$ & $\begin{array}{c}-3.08 * * \\
(-2.54)\end{array}$ \\
\hline $\begin{array}{l}\text { Fee income to } \\
\text { total income }\end{array}$ & & & & & & $\begin{array}{c}8.93 * * * \\
(2.64)\end{array}$ & $\begin{array}{c}15.63 * \\
(1.90)\end{array}$ & $\begin{array}{c}2.29 \\
(1.19)\end{array}$ & $\begin{array}{l}6.36 * \\
(1.66)\end{array}$ & $\begin{array}{c}9.47 * * * \\
(2.86)\end{array}$ \\
\hline $\begin{array}{l}\text { Core deposits to } \\
\text { total assets }\end{array}$ & & & & & & $\begin{array}{l}2.78 * \\
(1.93)\end{array}$ & $\begin{array}{c}6.23 \\
(1.23)\end{array}$ & $\begin{array}{c}2.95 \\
(1.58)\end{array}$ & $\begin{array}{l}-2.19 \\
(-0.87)\end{array}$ & $\begin{array}{c}2.94 * * \\
(2.56)\end{array}$ \\
\hline $\begin{array}{l}\text { Large CDs to } \\
\text { total assets }\end{array}$ & & & & & & $\begin{array}{c}7.77 * * \\
(1.99)\end{array}$ & $\begin{array}{l}13.87 \\
(1.39)\end{array}$ & $\begin{array}{c}0.71 \\
(0.30)\end{array}$ & $\begin{array}{c}8.70 \\
(1.30)\end{array}$ & $\begin{array}{c}4.37 * * \\
(2.06)\end{array}$ \\
\hline $\mathrm{R}^{2}$ & 0.05 & 0.07 & 0.15 & 0.14 & 0.09 & 0.08 & 0.1 & 0.2 & 0.18 & 0.19 \\
\hline $\mathrm{N}$ & 1464 & 477 & 234 & 316 & 437 & 1464 & 477 & 234 & 316 & 437 \\
\hline
\end{tabular}

$* * *, * *, *$ indicate significance at the $1 \%, 5 \%$, and $10 \%$ level, respectively. 
Table 7: Comparing Capitalization between Publicly Traded and Non-Publicly Traded Banking Organizations

CAPITAL (ratio of equity to total assets) is regressed on public dummy, firm characteristics, time-effect dummies (not reported), and Federal Reserve District dummies (not reported). Robust t-statistics are in parentheses.

\begin{tabular}{|c|c|c|c|c|c|c|c|c|c|c|}
\hline & All Obs. & Size 1 & Size 2 & Size 3 & Size 4 & All Obs. & Size 1 & Size 2 & Size 3 & Size 4 \\
\hline $\begin{array}{l}\text { Public } \\
\text { ownership }\end{array}$ & $\begin{array}{c}-0.07 \\
(-0.57)\end{array}$ & $\begin{array}{c}0.23 \\
(1.28)\end{array}$ & $\begin{array}{c}-0.26 \\
(-1.19)\end{array}$ & $\begin{array}{c}-0.20 \\
(-0.91)\end{array}$ & $\begin{array}{c}-0.27 \\
(-0.83)\end{array}$ & $\begin{array}{l}0.004 \\
(0.03)\end{array}$ & $\begin{array}{c}0.22 \\
(1.27)\end{array}$ & $\begin{array}{c}-0.15 \\
(-0.75)\end{array}$ & $\begin{array}{c}-0.02 \\
(-0.12)\end{array}$ & $\begin{array}{c}-0.05 \\
(-0.14)\end{array}$ \\
\hline $\begin{array}{l}\text { Log of total } \\
\text { assets }\end{array}$ & $\begin{array}{c}-0.22 * * * \\
(-3.76)\end{array}$ & $\begin{array}{c}-0.34 * * * \\
(-3.70)\end{array}$ & $\begin{array}{c}-0.24 \\
(-0.44)\end{array}$ & $\begin{array}{c}-0.17 \\
(-0.34)\end{array}$ & $\begin{array}{l}-0.40 \\
(-0.86)\end{array}$ & $\begin{array}{c}-0.17 * * * \\
(-2.76)\end{array}$ & $\begin{array}{c}-0.33 * * * \\
(-3.16)\end{array}$ & $\begin{array}{c}-0.19 \\
(-0.39)\end{array}$ & $\begin{array}{c}-0.12 \\
(-0.27)\end{array}$ & $\begin{array}{c}-0.11 \\
(-0.24)\end{array}$ \\
\hline $\begin{array}{l}\text { Total loans to } \\
\text { total assets }\end{array}$ & & & & & & $\begin{array}{c}-4.73 * * * \\
(-9.16)\end{array}$ & $\begin{array}{c}-1.80 * * \\
(-2.01)\end{array}$ & $\begin{array}{c}-5.92 * * * \\
(-4.86)\end{array}$ & $\begin{array}{c}-4.61 * * * \\
(-6.24)\end{array}$ & $\begin{array}{c}-6.30 * * * \\
(-7.82)\end{array}$ \\
\hline $\begin{array}{l}\text { C\&I loans to } \\
\text { total loans }\end{array}$ & & & & & & $\begin{array}{c}-0.08 \\
(-0.17)\end{array}$ & $\begin{array}{c}0.70 \\
(0.96)\end{array}$ & $\begin{array}{c}-0.14 \\
(-0.13)\end{array}$ & $\begin{array}{c}-0.93 \\
(-1.23)\end{array}$ & $\begin{array}{c}-0.43 \\
(-0.50)\end{array}$ \\
\hline $\begin{array}{l}\text { onsumer loans } \\
\text { to total loans }\end{array}$ & & & & & & $\begin{array}{c}1.47 * * * \\
(2.95)\end{array}$ & $\begin{array}{c}2.25 * * * \\
(3.25)\end{array}$ & $\begin{array}{c}0.65 \\
(0.73)\end{array}$ & $\begin{array}{l}1.41 * \\
(1.80)\end{array}$ & $\begin{array}{c}0.37 \\
(0.38)\end{array}$ \\
\hline $\begin{array}{l}\text { Fee income to } \\
\text { total income }\end{array}$ & & & & & & $\begin{array}{c}-1.75 \\
(-1.27)\end{array}$ & $\begin{array}{c}-1.88 \\
(-0.78)\end{array}$ & $\begin{array}{l}1.76 \\
(0.88)\end{array}$ & $\begin{array}{l}-2.72 * * \\
(-1.99)\end{array}$ & $\begin{array}{c}-4.66 * * \\
(-2.33)\end{array}$ \\
\hline $\begin{array}{l}\text { Core deposits to } \\
\text { total assets }\end{array}$ & & & & & & $\begin{array}{c}-1.20 * * \\
(-2.19)\end{array}$ & $\begin{array}{c}0.72 \\
(0.86)\end{array}$ & $\begin{array}{c}-2.84 * * * \\
(-2.60)\end{array}$ & $\begin{array}{c}-2.09 * * \\
(-2.28)\end{array}$ & $\begin{array}{c}-0.55 \\
(-0.56)\end{array}$ \\
\hline $\begin{array}{l}\text { Large CDs to } \\
\text { total assets }\end{array}$ & & & & & & $\begin{array}{l}-1.63 * \\
(-1.67)\end{array}$ & $\begin{array}{c}-1.64 \\
(-1.18)\end{array}$ & $\begin{array}{c}-0.63 \\
(-0.33)\end{array}$ & $\begin{array}{c}-1.24 \\
(-0.82)\end{array}$ & $\begin{array}{c}-2.76 \\
(-1.51)\end{array}$ \\
\hline $\mathrm{R}^{2}$ & 0.17 & 0.20 & 0.18 & 0.17 & 0.19 & 0.22 & 0.23 & 0.26 & 0.24 & 0.27 \\
\hline $\mathrm{N}$ & 10821 & 2798 & 1991 & 2792 & 3240 & 10821 & 2798 & 1991 & 2792 & 3240 \\
\hline
\end{tabular}

$* * *, * *, *$ indicate significance at the $1 \%, 5 \%$, and $10 \%$ level, respectively. 


\section{Table 8: Comparing Bankruptcy Risk between Publicly Traded and Non-Publicly Traded Banking Organizations}

Z-SCORE (measuring probability of bankruptcy) is regressed on public dummy, firm characteristics, time-effect dummies (not reported), and Federal Reserve District dummies (not reported). Robust t-statistics are in parentheses.

\begin{tabular}{|c|c|c|c|c|c|c|c|c|c|c|}
\hline & All Obs. & Size 1 & Size 2 & Size 3 & Size 4 & All Obs. & Size 1 & Size 2 & Size 3 & Size 4 \\
\hline $\begin{array}{l}\text { Public } \\
\text { ownership }\end{array}$ & $\begin{array}{l}12.73 \\
(1.01)\end{array}$ & $\begin{array}{l}35.87^{*} \\
(1.92)\end{array}$ & $\begin{array}{l}23.05 \\
(0.84)\end{array}$ & $\begin{array}{c}-67.92^{* * * *} \\
(-2.79)\end{array}$ & $\begin{array}{l}-17.53 \\
(-0.57)\end{array}$ & $\begin{array}{c}14.54 \\
(1.16)\end{array}$ & $\begin{array}{l}31.93^{*} \\
(1.76)\end{array}$ & $\begin{array}{l}30.12 \\
(1.08)\end{array}$ & $\begin{array}{c}-62.28 * * * \\
(-2.64)\end{array}$ & $\begin{array}{l}-11.21 \\
(0.706)\end{array}$ \\
\hline $\begin{array}{l}\text { Log of total } \\
\text { assets }\end{array}$ & $\begin{array}{c}11.25 * * \\
(2.20)\end{array}$ & $\begin{array}{l}-2.82 \\
(-0.21)\end{array}$ & $\begin{array}{l}69.96 \\
(0.80)\end{array}$ & $\begin{array}{l}46.32 \\
(0.59)\end{array}$ & $\begin{array}{l}33.00 \\
(0.90)\end{array}$ & $\begin{array}{c}15.96 * * * \\
(3.03)\end{array}$ & $\begin{array}{c}-0.56 \\
(-0.04)\end{array}$ & $\begin{array}{l}59.19 \\
(0.66)\end{array}$ & $\begin{array}{l}50.07 \\
(0.66)\end{array}$ & $\begin{array}{l}32.54 \\
(0.94)\end{array}$ \\
\hline $\begin{array}{l}\text { Total loans to } \\
\text { total assets }\end{array}$ & & & & & & $\begin{array}{c}-138.6^{* * *} \\
(-4.52)\end{array}$ & $\begin{array}{l}-98.96 \\
(-1.49)\end{array}$ & $\begin{array}{l}-119.94 \\
(-1.38)\end{array}$ & $\begin{array}{l}-88.56 * \\
(-1.72)\end{array}$ & $\begin{array}{c}-186.7^{* * * *} \\
(-3.52)\end{array}$ \\
\hline $\begin{array}{l}\text { C\&I loans to } \\
\text { total loans }\end{array}$ & & & & & & $\begin{array}{l}-35.94 \\
(-0.79)\end{array}$ & $\begin{array}{c}132.37 * \\
(1.67)\end{array}$ & $\begin{array}{l}-97.87 \\
(-0.62)\end{array}$ & $\begin{array}{l}-85.13 \\
(-1.13)\end{array}$ & $\begin{array}{c}-154.7 * * * \\
(-3.27)\end{array}$ \\
\hline $\begin{array}{l}\text { Consumer loans } \\
\text { to total loans }\end{array}$ & & & & & & $\begin{array}{l}69.17 * \\
(1.87)\end{array}$ & $\begin{array}{l}78.63 \\
(1.28)\end{array}$ & $\begin{array}{l}-125.82 \\
(-1.13)\end{array}$ & $\begin{array}{c}205.10 * * \\
(2.48)\end{array}$ & $\begin{array}{l}61.75 \\
(0.95)\end{array}$ \\
\hline $\begin{array}{l}\text { Fee income to } \\
\text { total income }\end{array}$ & & & & & & $\begin{array}{c}-216.0 * * * \\
(-3.28)\end{array}$ & $\begin{array}{c}-161.48 \\
(-1.50)\end{array}$ & $\begin{array}{l}-86.23 \\
(-0.61)\end{array}$ & $\begin{array}{c}-305.9^{* * *} \\
(-2.83)\end{array}$ & $\begin{array}{l}-303.77 \\
(-1.44)\end{array}$ \\
\hline $\begin{array}{l}\text { Core deposits to } \\
\text { total assets }\end{array}$ & & & & & & $\begin{array}{l}-51.77 \\
(-1.12)\end{array}$ & $\begin{array}{c}-110.05 \\
(-1.15)\end{array}$ & $\begin{array}{l}-27.89 \\
(-0.21)\end{array}$ & $\begin{array}{l}59.67 \\
(0.78)\end{array}$ & $\begin{array}{l}-27.95 \\
(-0.41)\end{array}$ \\
\hline $\begin{array}{l}\text { Large CDs to } \\
\text { total assets }\end{array}$ & & & & & & $\begin{array}{c}-148.5^{* *} \\
(-2.12)\end{array}$ & $\begin{array}{l}-203.2 \\
(-1.64)\end{array}$ & $\begin{array}{c}2.09 \\
(0.01)\end{array}$ & $\begin{array}{l}-100.48 \\
(-0.81)\end{array}$ & $\begin{array}{c}-178.14 \\
(-1.49)\end{array}$ \\
\hline $\mathrm{R}^{2}$ & 0.14 & 0.16 & 0.16 & 0.2 & 0.19 & 0.17 & 0.17 & 0.18 & 0.26 & 0.27 \\
\hline $\mathrm{N}$ & 1464 & 477 & 234 & 316 & 437 & 1464 & 477 & 234 & 316 & 437 \\
\hline
\end{tabular}

$* * *, * *, *$ indicate significance at the $1 \%, 5 \%$, and $10 \%$ level, respectively. 
Table 9: Comparing Supervisory Ratings between Publicly Traded and Non-Publicly Traded Banking Organizations

BOPEC rating is regressed on public dummy, firm characteristics, time-effect dummies (not reported), and Federal Reserve District dummies (not reported). Robust t-statistics are in parentheses.

\begin{tabular}{|c|c|c|c|c|c|c|c|c|c|c|}
\hline & All Obs. & Size 1 & Size 2 & Size 3 & Size 4 & All Obs. & Size 1 & Size 2 & Size 3 & Size 4 \\
\hline $\begin{array}{l}\text { Public } \\
\text { ownership }\end{array}$ & $\begin{array}{c}0.10 * * * \\
(2.86)\end{array}$ & $\begin{array}{c}0.02 \\
(0.37)\end{array}$ & $\begin{array}{c}0.12 * * * \\
(2.10)\end{array}$ & $\begin{array}{c}0.21 * * * \\
(2.78)\end{array}$ & $\begin{array}{c}0.32 * * * \\
(3.28)\end{array}$ & $\begin{array}{c}0.09 * * \\
(2.47)\end{array}$ & $\begin{array}{c}0.02 \\
(0.36)\end{array}$ & $\begin{array}{l}0.09 * \\
(1.68)\end{array}$ & $\begin{array}{l}0.18 * * \\
(2.37)\end{array}$ & $\begin{array}{c}0.25 * * * \\
(2.67)\end{array}$ \\
\hline $\begin{array}{l}\text { Log of total } \\
\text { assets }\end{array}$ & $\begin{array}{c}-0.05 * * * \\
(-2.91)\end{array}$ & $\begin{array}{c}0.01 \\
(0.33)\end{array}$ & $\begin{array}{l}-0.03 \\
(-0.24)\end{array}$ & $\begin{array}{c}-0.04 \\
(-0.28)\end{array}$ & $\begin{array}{c}-0.30 * * * \\
(-2.16)\end{array}$ & $\begin{array}{c}-0.07 * * * \\
(-4.03)\end{array}$ & $\begin{array}{l}-0.01 \\
(-0.17)\end{array}$ & $\begin{array}{c}-0.01 \\
(-0.11)\end{array}$ & $\begin{array}{l}-0.10 \\
(-0.66)\end{array}$ & $\begin{array}{c}-0.35 * * * \\
(-2.70)\end{array}$ \\
\hline $\begin{array}{l}\text { Total loans to } \\
\text { total assets }\end{array}$ & & & & & & $\begin{array}{c}0.93 * * * \\
(8.08)\end{array}$ & $\begin{array}{c}0.72 * * * \\
(2.90)\end{array}$ & $\begin{array}{c}1.18 * * * \\
(5.35)\end{array}$ & $\begin{array}{c}0.90 * * * \\
(4.46)\end{array}$ & $\begin{array}{c}0.94 * * * \\
(5.43)\end{array}$ \\
\hline $\begin{array}{l}\text { C\&I loans to } \\
\text { total loans }\end{array}$ & & & & & & $\begin{array}{c}0.18 \\
(1.34)\end{array}$ & $\begin{array}{c}-0.09 \\
(-0.36)\end{array}$ & $\begin{array}{l}-0.15 \\
(-0.54)\end{array}$ & $\begin{array}{c}0.31 \\
(1.29)\end{array}$ & $\begin{array}{l}0.45 * * \\
(2.13)\end{array}$ \\
\hline $\begin{array}{l}\text { Consumer loans } \\
\text { to total loans }\end{array}$ & & & & & & $\begin{array}{c}-0.54 * * * \\
(-4.05)\end{array}$ & $\begin{array}{l}-0.44 * \\
(-1.84)\end{array}$ & $\begin{array}{c}-0.39 \\
(-1.58)\end{array}$ & $\begin{array}{c}-0.49 * * \\
(-2.21)\end{array}$ & $\begin{array}{c}-0.76 * * * \\
(-3.14)\end{array}$ \\
\hline $\begin{array}{l}\text { Fee income to } \\
\text { total income }\end{array}$ & & & & & & $\begin{array}{c}1.38 * * * \\
(5.78)\end{array}$ & $\begin{array}{c}1.39 * * * \\
(3.87)\end{array}$ & $\begin{array}{l}0.63 * \\
(1.82)\end{array}$ & $\begin{array}{c}1.28 * * * \\
(3.30)\end{array}$ & $\begin{array}{c}2.17 * * * \\
(4.28)\end{array}$ \\
\hline $\begin{array}{l}\text { Core deposits to } \\
\text { total assets }\end{array}$ & & & & & & $\begin{array}{l}-0.26 * \\
(-1.81)\end{array}$ & $\begin{array}{l}-0.42 \\
(-1.52)\end{array}$ & $\begin{array}{c}-0.26 \\
(-0.98)\end{array}$ & $\begin{array}{l}-0.44^{*} \\
(-1.70)\end{array}$ & $\begin{array}{c}-0.19 \\
(0.2389)\end{array}$ \\
\hline $\begin{array}{l}\text { Large CDs to } \\
\text { total assets }\end{array}$ & & & & & & $\begin{array}{c}0.86 * * * \\
(3.29)\end{array}$ & $\begin{array}{c}1.32 * * * \\
(3.17)\end{array}$ & $\begin{array}{c}0.72 \\
(1.46)\end{array}$ & $\begin{array}{c}0.39 \\
(0.75)\end{array}$ & $\begin{array}{l}0.89 * * \\
(2.12)\end{array}$ \\
\hline $\mathrm{R}^{2}$ & 0.12 & 0.13 & 0.14 & 0.14 & 0.15 & 0.17 & 0.18 & 0.19 & 0.18 & 0.23 \\
\hline $\mathrm{N}$ & 9403 & 2532 & 1821 & 2487 & 2563 & 9403 & 2532 & 1821 & 2487 & 2563 \\
\hline
\end{tabular}

$* * *, * *, *$ indicate significance at the $1 \%, 5 \%$, and $10 \%$ level, respectively. 
Table 10: Same Firm Comparison of Banking Firms' Risk Before and After Going Public

This table reports the Change in Relative Risk (CRR) before and after the banking organization went public.

\begin{tabular}{|c|c|c|c|c|}
\hline CRR & $\begin{array}{l}\text { Mean }^{\mathrm{a}} \\
\text { (Median) }\end{array}$ & $\begin{array}{l}\text { t-statistic } \\
\text { (p-value) }\end{array}$ & $\begin{array}{l}\text { Signed-Rank } \\
\text { (p-value) }\end{array}$ & $\mathrm{N}$ \\
\hline \multicolumn{5}{|c|}{ Panel A: CRRs computed from mean difference in risk between subject BHCs and peer } \\
\hline BADLOAN & $\begin{array}{c}2.099 \\
(17.600)\end{array}$ & $\begin{array}{c}0.253 \\
(0.800)\end{array}$ & $\begin{array}{c}856.00 * \\
(0.063)\end{array}$ & 136 \\
\hline CHARGEOFF & $\begin{array}{c}4.001 \\
(8.960)\end{array}$ & $\begin{array}{c}0.723 \\
(0.435)\end{array}$ & $\begin{array}{c}895.00 * \\
(0.052)\end{array}$ & 136 \\
\hline CAPITAL & $\begin{array}{c}-22.200 \\
(-39.200)\end{array}$ & $\begin{array}{l}-1.353 \\
(0.178)\end{array}$ & $\begin{array}{c}-1034.000 * \\
(0.024)\end{array}$ & 136 \\
\hline BOPEC & $\begin{array}{l}-0.005 \\
(0.038)\end{array}$ & $\begin{array}{l}-0.098 \\
(0.922)\end{array}$ & $\begin{array}{l}-98.500 \\
(0.779)\end{array}$ & 113 \\
\hline \multicolumn{5}{|c|}{ Panel B: CRRs computed from median difference in risk between subject BHCs and peer } \\
\hline BADLOAN & $\begin{array}{c}8.110 \\
(19.260)\end{array}$ & $\begin{array}{c}0.997 \\
(0.320)\end{array}$ & $\begin{array}{c}1288.000 * * * * \\
(0.005)\end{array}$ & 136 \\
\hline CHARGEOFF & $\begin{array}{c}8.361 \\
(7.700)\end{array}$ & $\begin{array}{c}2.075 * * \\
(0.040)\end{array}$ & $\begin{array}{c}1391.000 * * * \\
(0.002)\end{array}$ & 136 \\
\hline CAPITAL & $\begin{array}{c}-31.079 \\
(-23.000)\end{array}$ & $\begin{array}{c}-2.078 * * \\
(0.040)\end{array}$ & $\begin{array}{c}-1123.000 * * \\
(0.014)\end{array}$ & 136 \\
\hline BOPEC & $\begin{array}{c}0.023 \\
(0.164)\end{array}$ & $\begin{array}{c}0.376 \\
(0.708)\end{array}$ & $\begin{array}{l}177.000 \\
(0.610)\end{array}$ & 113 \\
\hline \multicolumn{5}{|c|}{ Panel C } \\
\hline SDROA & $\begin{array}{c}0.220 \\
(-2.000)\end{array}$ & $\begin{array}{c}0.219 \\
(0.827)\end{array}$ & $\begin{array}{c}-1058.500 * * \\
(0.012)\end{array}$ & 129 \\
\hline SDROE & $\begin{array}{l}-246.053 \\
(-59.300)\end{array}$ & $\begin{array}{l}-1.017 \\
(0.311)\end{array}$ & $\begin{array}{c}-1553.500 * * * \\
(0.0002)\end{array}$ & 129 \\
\hline Z-Score & $\begin{array}{l}-10.306 \\
(-16.816)\end{array}$ & $\begin{array}{l}-0.968 \\
(0.335)\end{array}$ & $\begin{array}{c}-669.500 \\
(0.116)\end{array}$ & 129 \\
\hline
\end{tabular}

${ }^{a}$ in basis points except for Z-Score and BOPEC

$* * *, * *, *$ indicate significance at the $1 \%, 5 \%$, and $10 \%$ level, respectively. 